\title{
ON THE COSTS OF INWARD-LOOKING DEVELOPMENT: HISTORICAL PERSPECTIVES ON PRICE DISTORTIONS, GROWTH, AND DIVERGENCE IN LATIN AMERICA FROM THE 1930S TO THE 1980S
}

Alan M. Taylor

Working Paper 5432

\author{
NATIONAL BUREAU OF ECONOMIC RESEARCH \\ 1050 Massachusetts Avenue \\ Cambridge, MA 02138 \\ January 1996
}

I thank Andrew Warner for sharing his data and for helpful discussions. I acknowledge the useful comments of Nick Crafts, Steve Dowrick, Cynthia Taft Morris, and audiences at the Economic History Association Annual Meetings and at the University of Warwick. I am solely responsible for all errors. This paper is part of NBER's research program in the Development of the American Economy. Any opinions expressed are those of the author and not those of the National Bureau of Economic Research.

(C) 1996 by Alan M. Taylor. All rights reserved. Short sections of text, not to exceed two paragraphs, may be quoted without explicit permission provided that full credit, including $\odot$ notice, is given to the source. 


\title{
ON THE COSTS OF INWARD-LOOKING DEVELOPMENT: HISTORICAL PERSPECTIVES ON PRICE DISTORTIONS, GROWTH, AND DIVERGENCE IN \\ LATIN AMERICA FROM THE \\ 1930S TO THE 1980S
}

\begin{abstract}
From the 1930s to the 1980s, economic policies in Latin America epitomized the inwardlooking model of development. The model emerged in the Depression, and was later codified in unorthodox economic theories. Even though economic performance was seen as disappointing by the 1960 s, the distortions of the regime were long lived, persisting and worsening into the 1970s and 1980s. I examine the costs of distortions and explore the structural differences between growth dynamics in Latin America and elsewhere. Distortions had pervasive and profound effects on many aspects of the growth process, and help explain divergent development in the region.
\end{abstract}
Alan M. Taylor
Department of Economics Northwestern University 2003 Sheridan Road Evanston, IL 60208-2600 and NBER 


\title{
On the Costs of Inward-Looking Development: Historical Perspectives on Price Distortions, Growth, and Divergence in Latin America from the 1930s to the 1980s
}

\begin{abstract}
"During the 1950s, 1960s, and 1970s a large number of development economists embraced the protectionist view... However, a small group of academics embarked, independently, on major empirical investigations aimed at assessing the consequences of alternative trade regimes... these researchers argued that there was abundant evidence suggesting that more open economies had outperformed those countries pursuing protectionism. The poor performance of the Latin American countries, most of which had followed with almost religious zeal the dictates of import substitution, offered a dramatic contrast to the rapidly growing East Asian countries that had aggressively implemented outward-oriented strategies. Suddenly, this difference in performance which had been documented by the academic literature on trade orientation, became a fundamental topic in the public policy debate." 1
\end{abstract}

Setting the scene for his survey of the field, Sebastian Edwards succinctly summarized the paradigm shift in the last decade, a transformation built on the accumulated findings of years of research: that inward-looking development strategies were costly for growth: the distortions they engendered in the economic system compromised economic efficiency both statically and dynamically; those counties that avoided such pitfalls stood to benefit from allocative efficiency and fast growth; those that didn't risked short-run dead-weight losses, and long-run retardation and divergence relative to rich and fast-growing economies. The parable seemed nowhere more apparent than in the contrast between the virtuous export-oriented regimes of the Asia-Pacific region, and the villainous autarkic regimes of Latin America. Yet the evidence, even the technically-adept late-vintage findings from the "new" growth empirics, was, as Edwards noted in conclusion, still fragmentary, fragile, and in need of further attention: an important challenge for researchers was to obtain more reliable measures of openness and to "investigate in greater detail the channels through which greater outward orientation affects growth." 2 Such concerns motivate the present paper.

\footnotetext{
1 Edwards (1993, p. 1359)

2 Edwards (1993, p. 1390)
} 
The context is an examination of the causes of economic retardation in Latin America, and the analytic vehicle is an econometric approach rooted in the empirical growth tradition. The question is, of course, implicitly comparative: retardation relative to what? The standard comparison is with the outward-looking Asia-Pacific region. I follow this lead, but I ask whether this "between" sample comparison is the only benchmark we should employ. I also examine the question of "within" sample variation - what made for winners and losers in Latin America? This question is much harder, and points to the "measure of our ignorance" embedded in the residual variance of any empirical growth exercise: good luck, as well as good policy, matter for growth. Throughout, I emphasize the two issues raised above.

First, how can we measure "openness" in the broadest sense? Here, I make an appeal for using both price and quantity criteria, the former being preferred. ${ }^{3}$ Further, I argue that we might also profitably examine openness in capital markets and financial markets, including relative prices, exchange-rate stability, and black-market currency activity. These multiple openness criteria seem especially appropriate in the Latin American context, and encompass a broad range of possible interactions suggested by growth theory at the intersection of trade, capital flows, financial development, and accumulation. ${ }^{4}$ In the next section I discuss openness in the Latin American context since the 1930s.

Second, aside from a correlation of openness and growth, can we say anything about the channels or mechanisms which might underlie this seeming empirical regularity?

In subsequent sections I explore the theoretical basis for the reduced-form modeling approach so central to growth empirics at present, only to then discard it in favor of structural modeling - an approach which at least promises a description of the channels, mechanisms, and processes whereby distortions affect growth. The results accord well with theory and are applied to examine the relationship between openness and growth, with special reference to Latin America.

${ }^{3}$ Edwards rightly points to the futility of using trade to GDP ratios as an index of openness, since trade flows depend on endowments and economic structure of the economy. Still the use of this openness measure is commonly seen in the empirical literature. A thought experiment suffices to dismiss this approach: suppose two identical autarkic Heckscher-Ohlin economies stand adjacent but separated by an infinitely lugh wall; the wall falls down, and they then open to trade, becoming one market; their autarky prices would be identical, equal to the free-trade prices, and no trade would result. Edwards likewise considered inadequate the subjective measures of openness constructed by the World Bank and others; the preferred approach was a direct measurement of price distortions, the method followed here. (Edwards 1993, pp. 1386-88, 1390).

${ }^{4}$ For an example of multiple openness criteria see Sachs (1995). 


\title{
I. History
}

\section{A. Inward-Looking Development: Origins, 1930-50}

\begin{abstract}
"Latin American development experienced a turning-point during the 1930s. The contrast between 'before and after 1929' may often be exaggerated, but there is little doubt that the decade witnessed a closing toward international trade and finance, and a relative upsurge of import-substituting activities, primarily but not exclusively in manufacturing... Memories of the 1930s have profoundly influenced the region's attitude toward international trade and finance; per capita foreign trade indicators reached by the late 1920s were not surpassed in many nations until the 1960s." 5
\end{abstract}

As noted by Carlos Díaz Alejandro, the Great Depression still stands as the watershed in the economic history of modern Latin America. Since the colonial period, according to the standard view, the region had clung to export-orientation and policies of openness and macroeconomic orthodoxy. The policy orientation had held firm even through the comings and goings of the gold standard, a disruptive war, and the trade and capital-market volatility which beset small open economies, many of them poorly diversified and subject to the vicissitudes of the commodity lottery.

The thumbnail sketch blurs the details, of course. The pre-1929 details require some elaboration in passing. Export-led growth was not an unqualified success. The region could not hold on to a claim for the highest per capita incomes in the world, as it might have in the colonial period pre-1700, before industrialization enriched the core ${ }^{6}$ However, Latin America was still relatively rich by the standards of the periphery, countries which, in the international division of labor, had chosen to trade with the core rather than imitate it. ${ }^{7}$ John Coatsworth ascribes this slow pattern of growth and modernization to natural and institutional barriers which persisted until late into the nineteenth century, a pattern reminiscent of the southern European periphery. ${ }^{8}$ Certainly, the exact mechanics of the so-called export-led growth phase invite further investigation. A coherent analysis of the period is needed which encompasses the considerable cross-country variation in policies and performance, since it is by no means the case that all countries at all times embraced a policy of openness-but such issues are beyond the scope of this paper. ${ }^{9}$

Heterogeneity of individual country experience intrudes after 1929 as well. Undeniably, the simple description is surely correct in pointing to the enormous 'before and after 1929' contrast on the policy dimension, and to the dramatic relative retardation of the region ever since. ${ }^{10}$ However, it is by no means the case that policy

5 Díaz Alcjandro (1984b, p. 17)

${ }^{6}$ One source places Latin American income per capita at $\$ 245$ (1960 prices) in 1800 , just above that of North America's $\$ 239$. See Bairoch (1981); cited in Bulmer-Thomas (1994, p. 27)

7 Lewis (1978).

8 Coatsworth (1993).

9 Bulmer-Thomas (1994).

10 Maddison (1989). 
response was uniform throughout the region. Díaz Alejandro highlighted a key dimension along which policies differed: larger countries and those with more autonomous public sectors engaged in "reactive" policy responses (e.g., Argentina, Brazil, Uruguay), whereas smaller countries and those with dependent governments were more "passive" (e.g., Cuba, Honduras, and Caribbean colonies). 11

On the foreign exchanges the "reactive" countries pursued aggressive devaluation strategies, with widespread use of multiple-exchange-rate systenı to discourage imports by twisting relative prices. Restoration of parity was given only lip service. Only the "passive" countries fought to maintain their pegs. Despite the memory of disastrous late-nineteenth century inflations under paper standards, policy makers added devaluations to their toolkit. Slack in the economies curtailed the inflationary pressure of substantial real devaluations. ${ }^{12}$ Exchange controls were needed to maintain external equilibrium since genuinely floating currencies were rare. ${ }^{13}$ The effect of these competitive devaluations were typical of policy response elsewhere in the world, and worked with some success, winning respectability for the unorthodox monetary experiments. ${ }^{14}$ Fiscal experimentation was limited, in part a consequence of limited tax bases, but some aggressive public works programs rounded out the aggregate deniand management. For example, Argentina struggled to close the fiscal gap, whilst Brazil embraced countercyclical policy more enthusiastically. All countries made efforts to diversify their tax bases. ${ }^{15}$

It was through trade and commodity markets that the first shocks hit, with sharp exogenous declines in the terms of trade in 1929-33 for most countries. ${ }^{16}$ The commodity lottery spared some and hurt others. Trade volumes collapsed. With a shift to import-competing activity seen as an inevitable long-term result of price changes the process was ushered along, not only by devaluations, but by price distortions in trade policy, with tariffs and quantitative restrictions both in use. The "passive" countries showed less initiative here, though even large countries were made to back down over trade concessions (e.g., Argentina and the Roca-Runciman treaty). In capital markets, little new foreign borrowing came in after 1930 and debt burdens grew large as real interest rates climbed during deflation. Foreign direct investment (FDI) went increasingly to import-substitution activities. Crisis drew scarce dome ic resources away from debt servicing and defaults ensued. ${ }^{17}$

11 Díaz Alejandro (1984b. p. 18).

12 Díaz Alejandro (1984b, pp. 23-25).

13 Bulmer-Tliomas (1994, p. 204).

14 Eichengreen (1985). Campa(1990).

15 Díaz Alejandro (1984b, pp. 29-36).

16 Díaz Alejandro (1984b, p. 19)

17 Díaz Alejandro (1984b. pp. 20-21, 27-28). 
In summary, by the late 1930 s policy makers had a broad arsenal of new instruments at their disposal. Most had been fundamentally a response to external shocks-worsening balance-of-payments disequilibria, curtailed lending, terms-of-trade shocks-which, as a whole, implied, or seemed to imply, large-scale structural adjustment with interim adjustment costs. A large scale reallocation of resources ensued, but overall performance was respectable. Recovery was built around both import-substituting industrialization (ISI), home demand, and export growth, though the first usually garners the most attention. ${ }^{18}$

The 1930s rebound was more rapid than elsewhere, encouraging continued use of the same instruments. Enforced autarky through World War Two did nothing to dislodge the new policy regime, but rather appeared to augment its reputation: indeed, even in the words of one of ISI's critics, the 1940s were the "golden age of import-substituting industrialization in Latin America." 19 Growth rates were high across the board and unequaled in the rest of the world, and the economies of the region handled further supply and demand shocks with resilience, encouraging smug satisfaction among policymakers and a sense of a bright future. The inward-looking typology changed, reflecting geography more than size-ISI was pursued most vigorously in the larger countries of the Southern Cone (Argentina, Brazil, Chile, an "ABC" synonym for ISI that would stick). Interventions were strengthened and extended, in terms of exchange controls and trade policies. Only the devaluation policy weakened, as the overvaluations of the 1950 s emerged during the reconstruction of the international monetary system-ironically, guaranteeing further balance-of-payments crises and continued chronic resort to the devaluation tool. 20

Thus, the 1950 structure of the Latin American economies differed markedly from that of 1929. The policy response to external shocks had created a new selfsufficient posture for the region, most notably in the reactive Southern Cone: retreat from the global economy was rapid, and persisted long into the future, as Latin America's share of trade began a long-run secular decline (Table 1). The new policies did not come as a result of new economic theory, but rather the force of circumstance in extreme economic crisis. This was to change, however: starting in the 1950s the unorthodox policy experiments which had softened the blow of the depression and the war had been clothed with the trappings of a new economic theory, propounded now as a "model" of economic development by a new schools of thought (the Dependency school and the Structuralists), and spread with heightened respectability to other countries within the region and beyond.

18 Bulmer-Thomas (1994, p. 212).

19 Díaz Alejandro (1984a, p. 341 ).

20 Díaz Alejandro (1984a). 


\section{B. Inward-Looking Development: Codification, 1950-70}

"The inward-looking model, particularly in the 1950s, is now seen as an aberrationcondemned by Latin American leaders and international organizations alike. The distortions associated with the model have become legendary, and its achievements dismissed....

Furthermore, the model was adopted in an explicit form just when the world economy and international trade were embarking on their longest and faster period of secular expansion. The timing of the model could not have been worse."21

In 1949 Raúl Prebisch joined CEPAL (the United Nations Economic Commission for Latin America). Prebisch's personal experience as an economist-his faith in free trade shattered by the events of the 1930s-mirrored the historical experience and political realities that gave the inward-looking model its force, credibility and influence.In the following years, under his intellectual leadership, CEPAL became the home and champion of the Structuralist school of economic thought. The cepalistas were closely aligned with the ideology of the dependistas and scholars such as Hans Singer, Ragnar Nurkse, and Paul Rosenstein-Rodan. ${ }^{22}$ The Prebisch-Singer thesis centered on the alleged properties of unequal exchange embedded in the international economic system and perpetuated by economic orthodoxy. Its principal manifestation was thought to be in trade: hence "elasticity pessimism", a belief in an inexorable tendency for the terms-of-trade to turn against the "periphery" (poor countries, commodity exporters), favoring the "center" (rich countries, exporters of manufactures). Trade was not the only supposed channel: a structural tendency of gains to flow to the center was see for capital and technology too.

To break the "center-periphery" system called for economic unorthodoxy in the form of autarkic responses: delinking, protectionism, trade and capital controls. ${ }^{23}$ To this end, ISI was the strategy of choice for postwar Latin America. It was most consistently adopted in the larger, semi-industrialized countries which had already succeeded in the first, "easy" stage of ISI. Included here were the Southern Cone (ABC) plus Colombia, Mexico, and Uruguay. Outside this six, adherence to ISI wavered, as in, say, Peru or Paraguay. It successes were a rapid resource reallocation toward manufacturing as demanded by the strategy, although the price to be paid were massive distortions and levels of inefficiency that precluded manufactured exports. ${ }^{24}$

Unorthodox monetary policies such as exchange controls and multiple exchange rate schemes, tolerated in depression and war, were discouraged by international pressure in the Bretton Woods era, and declined in prominence. The

21 Bulmer-Thomas (1994, p. 288).

22 Prebisch (1984); ECLA (1950a; 1950b); Nurkse (1961); Rosenstein-Rodan (1943); Singer (1950).

23 Kay (1989) offers a survey of Structuralism, Dependency Theory, and other aspects of the peculiarly Latin American theories of development. See also Palma (1987a; 1987c; 1987b).

24 Bulmer-Thomas (1994, chapter 9). 
tariff emerged as the most important policy instrument; ${ }^{25}$ and high tariffs were the norm by the end of the 1950s (Table 2). Most were not content to pursue a "market oriented ISI" approach, with flat tariff rates and a simple protection scheme à la Haberler, but favored the no-holds-barred "planning-oriented ISI" approach of the Structuralist school. ${ }^{26}$ This entailed micro-management, regulatory apparatuses, and a variegated nominal protection structure which opened up the policy of differential protection and further relative price twists as between intermediates inputs and the final goods; that is, even higher effective rates of protection (Table 3).

Of course, there was considerable heterogeneity within the region. Larger countries attempted to graft export promotion measures onto ISI, or tried other reforms; some hoped that regional integration and trading blocs might rescue the model, but substantive progress was scant. Smaller countries were less wed to ISI as a general rule. Examples, such as Bolivia, Paraguay and Peru, indicated that episodes of aggressive export-led growth were not unknown. ${ }^{27}$ Still, even these countries inherited, by the $1970 \mathrm{~s}$ and $1980 \mathrm{~s}$, measures of distortions to rival any in the region (see below). Thus, even experiments in outward orientation were no guarantee of a long-run successful switch toward globalization and integration into the world economy. Political turmoil, monetary instability, balance-of-payment crises, and sundry distractions could and did arise to divert policy and reverse reform.

The distortions were "legendary" if judged by endurance. It is quite apparent that the measures of distortions used for empirical purposes in this paper are consistent with the unusually high degree of tariff, exchange-rate, and other distortions which emerged in the 1950s and 1960s. Table 4 shows measures of black-market premia (BMPL), the relative price of capital (LNPIPY), and the rate of devaluation $(G X R)$ for the Latin America sample (see Appendix), and other subsamples used later. At this stage, the attempts at reforming the ISI approach in Latin America are reflected in distortions little different from the Asia-Pacific group. The Southern Cone had moderately higher distortions, as expected, but (judging from this data) the attempts in the region to foster export promotion and increased openness were not a total failure, creating some genuine hopes for improved economic performance. ${ }^{28}$ With hindsight, though, this era of moderate distortions and a turning away from the inward-looking model appears as a brief hiatus, a lost opportunity. For many countries, despite an early realization that ISI was unsustainable, the task of completely and permanently eliminating the distortions proved difficult. As we are about to see, by the 1970 s and 1980 s, many Latin American countries ranked very low in openness judged by these same criteria. In the long haul, the autarkic stance was hard to break.

\footnotetext{
25 Bulmer-Thomas (1994 pp. 278-81),

26 On these two flavors of ISI see Bhagwati (1984).

27 Bulmer-Thomas (1994, pp. 289-307).

28 Diaz Alejandro (1974).
} 


\title{
C. Inward-Looking Development: Persistence, 1970-90
}

\begin{abstract}
"Although the region has long since undergone a reversal of the ideology associated with ISI, the economic structure in place today contains vestiges of this attempt to achieve ind ustrial self-sufficiency. Factories constructed under ISI continue to operate today, and policies from this era remained intact well into the 1980 s despite disillusionment with them. As antecedents to current economic problems in the region, ISI policies have had a profound effect." 29
\end{abstract}

ISI was losing credibility. The critique: distortions hurt growth, causing the region to retard and diverge. This claim need not be merely conjectural. The distortions persisted into the 1970s and 1980s, and, given the richer data sources developed for these decades, we now have an opportunity to assess the empirical content of the critique and weigh the costs of inward-looking development. In remainder of the paper I assess the empirical record of growth in the 1970s and 1980s using panel data for a large set of countries, with special reference to Latin America.

My summary data on distortions for the period is shown in Table 5, including now a measure of tariff incidence $(O W T I)$. It is apparent that a Latin versus Asian divergence in openness emerged between the 1960s and the 1980s (compare Table 4). Arguably, it is here that Latin American growth prospects were compromised, since at earlier dates a policy contrast was harder to spot. This idea is echoed in the more subjective indices of trade policy: Korea, for example, often scores low on openness for the 1960s, while Brazil and Chile can sometimes rank surprizingly high by the same criteria. ${ }^{30}$

Table 5 allows a cursory comparison of distortions and growth performance in various subsamples, including Asia-Pacific and within it the fast-growing NIC subgroup (Korea, Taiwan, Hong Kong, Singapore); Latin America and within it the Southern Cone ("ABC" plus Uruguay and Paraguay, which neighbor the big three geographically and in distortion measures, and which are often considered Conical); and lastly the subgroups of qualifiers and non-qualifiers for fast growth selected according to the Sachs-Warner oplitical and openness criteria Within the panel data set, the contrasts in policy and growth across regions are clear. ${ }^{31}$

Look at distortions (Panel (a)). The "most virtuous" NIC4 group had, on average, relatively low black market premia $(6 \%)$, low tariffs $(6 \%)$, small capital price distortions (14\%) and exchange rate stability (GXR is zero). The larger Asia-Pacific sample is not far behind, and better than the world average. Latin America is the other side of the story-relatively high black-market premia (26\%), tariffs (22\%), capital price distortions $(27 \%)$, and rates of depreciation (37\% per annum). The Southern Cone ranks worse, excepting LNPIPY. Outside the Cone, some smaller and previously export-led economies rose high in the distortion rankings (e.g., Peru, Bolivia). Within the Cone

29 Cardoso and Helwege (1992, p. 84).

30 See, for example, the discussion in Edwards (1993, pp. 1386-7).

31 See Sachs and Warner (1995). 
every country ranks above the Latin median level of distortions on at least two criteria out of four. Argentina is above the median on every count, ranks first on average distortion levels, and is, so to speak, the canonical Conical.

Turning to growth (Panel (b)), Argentina ranks low, with negative growth rates. However, between the Southern Cone and other Latin countries it is hard to see any differential penalty for policy differences. Overall the Southern Cone sample grew at $1 \%$ per annum, the region at $0.5 \%$ per annum. This suggests that an explanation of within-group economic performance may be difficult for Latin America. Between Latin America and the Asia-Pacific group, the contrasts are strark: the NICs grew at $6.5 \%$ per annum and the Asia-Pacific group as a whole at $3.4 \%$ per annum. All of the Latins sit in the Sachs-Warner nonqualifying group (they all fail on openness), a subset which grew at $0.6 \%$ per annum on average, five times slower than the qualifiers $3.2 \%$ per annum.

Why was this so? There are really two questions. First, why did Latin America's disillusionment with inward-looking strategies in the 1960s not lead to a complete and permanent reform, with a regime of low distortions lasting through the 1970s and 1980s: Such a goal was not unreasonable since Latin America's distortion levels were not out of line in the 1960s (Table 4). What combination of internal politics, external shocks, or other factors conspired to prevent it? I leave that question for later, and here take the distortions and policy regime as given. I address the second question: How costly was the inward-looking development path? I have explored the dynamic inefficiencies for one country, Argenitna, already, finding that distortions might explain poor performance. I now extend the terms of the analysis and the scope of the sample for a comparative treatment of growth in the region as a whole. ${ }^{32}$

\section{Theory}

This section reviews the bases of models in "new" and "old" growth theory, and their empirical application. "New" growth theory sought to extend the basic RamseySolow-Swan frameworks to endogenize and examine the various channels of the growth process, and, as a result, empirical work has extended its scope beyond mere growth accounting into ever more refined econometric models of growth determinants. ${ }^{33}$ The many and varied models now built confront, for example, the endogenous or exogenous behavior of investment, human capital, population and

32 On the Argentine analysis, see Taylor (1994c; 1994b). Several authors have examine the roles of distortions in economic growth, often with reference to Latin America (Agarwala 1983; Barro 1991; Brander and Dowrick 1994; De Gregorio 1992; Easterly 1993; Edwards 1992; Jones 1992). The literature associating exports with growth was begun by a seminal contribution by Feder (1983), a topic reviened by Edwards (1993).

33 The theoretical and empirical discussions follow Taylor (1996), a related work on the Asia-Pacific region, which compares trade and migration as forces in the Asia-Pacific growth dynamic. Here the empirical framework is exploited to examine Latin America in the Asia-Pacific "mirror." 
fertility choices, financial development, foreign investment, even democracy and politics. ${ }^{34}$

To step back from a specific model, let us pause to consider the basic approach. In its most general possible formulation, a theoretical growth model is simply a dynamical system, describing the evolution of a set of state variables $x$ and a set of control variables $"$ over points in time $t$.

The state variables follow trajectories $x_{t}$ and include conventional economic stock variables: endowments such as physical and human capital, population, and also "technology," suitably measured. Conventionally, and since it is a function of these state variables, output is often included as another implicit state variable, as it is the major growth variable of interest. Control variables $u_{t}$ may be endogenously determined and include the conventional economic flow variables: investment in the accumulation of physical or human capital, population growth, research as it affects technology, and so forth. The control variables affect the rate of change of the state variables through what I will term a "laws-of-motion" equation

(1) $d x_{t} / d t=f\left(u_{t} ; a\right)$,

where $a$ is a set of environmental parameters that might also affect the evolution of the state variables, including economic policies such as taxes and institutional structures such as property rights.

Often, attention is given to only one element on the left-hand side of (1). When $d x_{t} / d t$ is just the growth rate of output $d \ln y t / d t$, and the controls $u_{t}$ are the growth rates of inputs $d \ln v t / d t$, essentially (1) reduces to the production function oncedifferentiated, and its estimation. When that estimation is direct, it is called growth accounting, which amounts to weighting the various input growth contributions to output growth and deriving a residual measure of total factor productivty growth. ${ }^{35}$ However, when such estimation is econometric, it leads to what I will term a "growth accounting" regression

(la) $\quad d \ln y / d t=\alpha_{0}+\alpha_{1} d \ln v / d t+\alpha_{2} a+\varepsilon$.

34 Major theoretical contributions in this "new" growth tradition include the works of Lucas (1988) on human capital; Romer $(1986 ; 1989 ; 1990)$ on technological change and economies of scale; Becker et al. (1990) and Becker and Barro (1988) on fertility; Barro (1990) on government; Rebelo (1991) on policy analysis and growth; and Grossman and Helpman (1991) on dynamic comparative advantage. Major empirical efforts began with work on unconditional convergence by Abramovitz (1986) and Baumol (1986), following Maddison (1982). Studies of conditional convergence include the studies by Kormendi and Meguire (1985); Dowrick and Nguyen (1989); Barro (1991); and Mankiw et al. (1992) . For a recent survey of the field see Romer (1994), or the textbook treatment of Barro and Sala-i-Martin (1995)

35 The major contributions to the growth accounting literature include the methodological basis provided by Abramovitz (1956) and Solow (1956), complemented by a major empirical tradition running from Denison (1967) through to Jorgensen (1995). For obvious reasons, growth accounting, in itself, may be suggestive of growth mechanisms, but supplies no theory of economic growth per se; see (Barro and Sala-i-Martin 1995, chapter 10). 
This approach has been used in the recent empirical growth literature ${ }^{36}$ However, it suffers from a potential weakness; as the "new" growth theory stresses, the controls $u_{t}$ are probably endogenous variables determined according to some behavioral rule. The full characterization of that endogeneity is indeed the hallmark of new growth theory. ${ }^{37}$ Thus, equation (1) should be complemented by a "behavioral" equation, rounding out the description of the dynamical system, of the form

$$
u_{t}=g\left(x_{t} ; b\right)
$$

which describes the endogenous control choices $u_{t}$ as a function of current state $x_{t}$ and another set of putatively exogenous environmental parameters $b$.

The dynamical system is fully described by (1-2); theoretical attention is then given to an analysis of the (possibly multiple) equilibria and trajectories of the system. Econometrically, (1-2) should be viewed as a system of simultaneous equations, and (la) should be estimated with care for simultaneity bias arising from endogenous controls. In its own right, (2) may be usefully estimated as a "behavioral" regression

$$
u=\beta_{0}+\beta_{1} x+\beta_{2} b+\eta
$$

to provide details of the channels through which state variables and environmental parameters affect controls (e.g., factor accumulation) and, hence, growth.

Still, a delicate question remains: which variables are truly exogenous to the system? Clearly, empirical work can implement some standard tests to address this problem, but the specification may not be obvious. A popular and convenient, albeit costly, escape route exists; namely, to ignore the challenge of modeling the endogenous processes altogether, and retreat to a reduced form specification.

Integrating the dynamical system (1-2) forward over time yields a "trajectory" equation (3) $x(T)=h(x(0) ; a, b)$.

Such an approach may be applied to the trajectory of output to derive a reduced form "trajectory regression" where state evolution (in this case, the growth rate of output) depends only on initial conditions $x(0)$ and environmental parameters:

(3a) $\quad \mathrm{d} \ln y / \mathrm{d} t=\gamma_{0}+\gamma_{1} x(0)+\gamma_{2} a+\gamma_{3} b+\xi$.

The attraction of the last specification is clear; the initial conditions are predetermined and the endogeneity problem is finessed since the controls $u$ do not enter. There is a cost: a specification like (3a) cannot reveal the channels through which the environment affects growth. The benefit is that (3a) might suggest some relevant

36 Notable empirical contributions in this vein have come from Dowrick and Nguyen (1989) and Mankiw, Romer, and Weil (1992), two papers firmly in the Solovian tradition.

37 "Old" growth theory is not synonymous with exogenous growth. Of course, in the simple neoclassical growth model of Solow (1956) and Swan (1956), the savings rate, and, hence, accumulation in the closed economy are exogenous. However, the seminal contribution of Ramsey (1928) produced the first endogenous growth model: one where saving and accumulation follow an optimization rule (Barro and Sala-i-Martin 1995, chapters 1 and 2). "New" growth theory has now expanded the family of control variables subject to endogenous determination. 
environmental parameters which affect growth, and hence inspire investigation of likely channels through which such forces might operate.

It is fair to say that empirical work often embraces several different formulations in an attempt to describe the growth process fully. However, a cursory glance at the empirical growth literature reveals a myriad of formulations of the type (1a-3a) and even some hybrids. For example, omitted variables in one study often show up as highly significant in alternative studies, and in such cases it is hard to know which hypothesis to accept. In some cases authors have developed a hybrid approach to estimating ( $1 \mathrm{a}-3 \mathrm{a}$ ), including some endogenous variables in a reduced form (3a), but not others; or, alternatively, adding some controls to the growth accounting regression (1a), but not others. A serious problem is that of replication and robustness-one study may find a partial correlation but only when omitting variables found to be important in another study. This has been especially true in the case of political indicators as dependent variables. ${ }^{38}$

Thus, my empirical design follows three approaches, corresponding to specifications ( $1 \mathrm{a}-3 \mathrm{a})$. I begin by estimating the simplest specification, the reduced form (3a), which may serve to identify important exogenous influences on the the growth rate, albeit with no indication of the mechanism through which such forces operate. As a second step, I estimate a structural growth regression of the form (la), looking first at the obvious flow (control) variables for factor accumulation. I then extend the specification to admit environmental variables. I also allow endogenous controls, employing two-stage least squares (2SLS) to estimate (1a-2a). Endogeneity tests suggest few simultaneity problems, however ${ }^{39}$ In a third step, estimation of the behavioral regression (2a) yields insights into growth mechanisms-how economic environment affects growth indirectly through control variables in the structural equations.

The last estimations are the most novel element in this paper. Estimation of behavioral regressions (2a) is quite scarce in the current literature, yet remains the only way to identify the channels through which the economic environment affects growth. Almost exclusive attention has been lavished on the reduced form estimation (3a) throughout the empirical growth literature. In this paper, I argue that this imbalance in the empirical literature has prevented us from exploring the mechanics of economic

38 See Levine (1992).

39 The use of simultaneous equation methods (such as 2SLS, IV, or SUR) to address the econometric problem of endogenous controls is widespread (Barro and Sala-i-Martin 1995, chapter 12, for cxample). However, specification tests should be used to test the IV estimation against OLS, as in the simple Hausman test for simultaneity (Pindyck and Rubinfeld 1981, pp. 303-4),. The full information properties of 2 SLS cause it to dominate OLS asymptotically in large samples. However, it is not clear that in the small-sample situations encountered in the empirical growth literature that the IV specification choice is not made at the cost of inefficiency. In such scenarios, OLS may fit better and may be preferred (Greene 1993, pp. 615-6). 
development, as they are manifested at the behavioral level. Reduced form equations answer the question "what mattered for growth?"; but only a structural analysis of the behavioral regressions can answer the immediate follow-on question: "how did it matter?". For example, why do price distortions or financial repression retard economic growth? This is an empirical finding oft replicated, yet consistent with many possible theories, and multiple channels of influence. Do they affect investment? If so, how? Is the effect direct? Or is it indirect, acting, say, via the finacial system? It is these kinds of question, embedded at a slightly deeper level of the dynamics, that I will explore in this paper. I find that a number of complex interdependencies can be traced among various endogenous variables in the system, suggesting a multitude of influences by which various policies and other characteristics of the economic environment affects growth. These interactions can never be seen in a reduced form estimation, but using structural equations I can explore these relationships in much more detail. I can then use the results to explore some of the causes of development "failure" in Latin America, which, in comparative terms, can be evaluated relative to its natural counterpoint, the fast growing economies of the Asia-Pacific region. This is a long standing comparison in the economic development literature, but it is a contrast rarely examined at this level of detail in a quantitative framework. Whilst the estimates I offer suggest statistical significance for many variables in the structural regressions, the approach can also provide explanations of quantitative significance as to why autarkic or inward-looking policies (the absence of "openness"-broadly defined) was so costly in Latin America

\section{Empirics}

All the data I employ is publicly available in electronic form from three major sources: the World Data file compiled by the World Bank (WD); the latest Penn World Table due to Heston et al. (PWT); and Barro and Lee's compilation of panel data (BL) ${ }^{40}$ For this study, I constructed a pooled cross-county data set as averages for four successive five-year periods 1970-74, 1975-79, 1980-84, and 1985-89. The following variables are used in the study, and are fully described in a data appendix available from the author upon request; the appendix also discusses their expected empirical relationships. The principal explicandum is the growth rate, noted first; the other variables constitute control variables and policy parameters; sources appear in brackets:

40 Sec the reference list for full citations of these sources (The World Bank 1994; Heston, et al. 1994; Barro and Lee 1994). There is only the following exception: the variables $O N Q$ and $P N Q$ are taken from Sachs and Warner (1995) (denoted SW). The data sets cover a broad cross-section of countries in the postwar period (207 countries for 1950-1992 in the World Bank source). The analysis of these data sources is ubiquitous in the empirical growth literature (Barro 1991; Barro and Sala-i-Martin 1995; Dowrick and Nguyen 1989; Levine and Renelt 1992; Mankiw, Romer and Weil 1992: De Long and Summers 1991). 
GY: The growth rate of per capita GDP [PWT];

$L N Y O$ : The natural log of initial GDP per capita. [PWT];

$P Y R+S Y R+O$ : Initial years of primary and secondary schooling per person [BL];

$P+S$ : The average enrollment rate in primary and secondary schools $[\mathrm{BL}]$;

$C I$ : The ratio of real gross investment to real GDP [PWT];

GPOP: The growth rate of population [PWT];

FDIXY: The ratio of inbound foreign direct investment to GDP [WD];

$P N X I$ : A measure of primary product net export intensity [WD];

$P O P 15+0, P O P 65+0$ : Initial share of population aged under 15, over 65

[PWT];

$G$ : The share of government spending in GDP [PWT];

$P N Q$ : Political non-qualifier country in the Sachs-Warner classification [SW];

LNPIPY: The relative price of capital goods [PWT];

$B M P L$ : A measure of black-market premium on the exchange rate $[\mathrm{BL}]$;

OWTI: Own-weight tariff incidence [BL];

$O N Q$ : Openness non-qualifier country in the Sachs-Warner classification [SW];

GXR: The rate of depreciation of the currency [PWT];

$L L Y$ : The ratio of liquid liabilities in the financial system to GDP [BL].

\section{A. Growth determinants and unconditional convergence}

The empirical growth literature began with findings on unconditional convergence for groups of high-income economies like Maddison's sixteen. ${ }^{41}$ Table 6 replicates the basic findings. Here, I begin by estimating $(3 \mathrm{a})$ with $x(0)=\{\ln y(0)\}$, and no other controls besides initial income. Regression 1 reproduces the standardresult that, despite the unconditional convergence seen in the sample of currently-highincome countries (a tautology, of course) expanding the sample to middle- and lowincome countries suggests a tendency toward divergence in the world economy (in the $\beta$-convergence sense).

A recent innovation by Sachs and Warner suggests we think of qualifying criteria for membership in the "convergence club" based on political conditions and the degree of openness in the economy as measured by the $P N Q$ and $O N Q$ variables-two important aspects of the economic environment thought to affect growth performance. ${ }^{42}$ Regressions 2 and 3 augment the specification and replicate the SachsWarner findings for the pooled data used here-unconditional convergence is strong in the set of qualifiers (1.5\% per annum) and weak in the set of non-qualifiers $(0.3 \%$ per annum); the divergence result of Regression 1 follows from pooling across these

41 (Abramovitz 1986; Baumol 1986; Maddison 1982).

42 Sachs and Warner $(1994 ; 1995)$ work with a single cross-section 1970-89. Here, I utilize their definitions of qualifying countries $(O N Q=0$ and $P N Q=0)$ and consider all other countries to be nonqualifiers (Sachs and Warner omit several countries with insufficient data). 
sets. Regression 4 cuts the problem another way, by introducing dummy variables $(O N Q$ and $P N Q)$ into the unconditional convergence test, and is more suggestive: the growth penalty is most severe for openness non-qualification (3.2\% per annum lost on the growth rate) versus the penalty for political non-qualification ( $0.8 \%$ per annum). The augmented results suggest that trade policy and other environmental attributes, as they affect openness $(O N Q)$, are more critical for growth and convergence than the nature of the political regime $(P N Q) \cdot{ }^{43}$

\section{$B$. Growth determinants and conditional convergence: reduced-form estimation}

Illustrative as these results are, they only push back further the quest of the study: if openness and political conditions matter for growth, then how do they matter? Do they act as exogenous or endogenous forces? And through what channel(s) do they inhibit growth-investment? human capital accumulation? technological change? population growth? all of the above?

If we posit exogenous environmental variables underlying the classification of $O N Q$ and $P N Q$, then a natural way to begin is by introducing these underlying variables into a full reduced-form estimation of the type (3a). This I attempt in Table 7 for my full sample of countries in the pooled data. ${ }^{44}$ Note that I retain the $P N Q$ variable as an explanator since for the present study I am more concerned to identify the channels through which openness affects growth, not politics. ${ }^{45}$

In fact, in this expanded regression with many more controls than the Table 6 regressions, the $P N Q$ variable is insignificant as an explanator of growth. Our focus should therefore shift to the openness criteria, which always seemed the more powerful in explaining growth, even in Table 6. Here, openness is no longer a binary choice variable $(O N Q)$, but includes measures of black-market currency premia (BMPL), tariffs $(O W T I)$, and exchange-rate depreciation $(G X R)$. The regression includes other distortion measures like the relative price of capital (LNPIPY), and the size of government $(G)$; and controls for financial development ( $L L Y)$ and resource abundance $(P N X I)$. All the above controls are contemporaneous, and also included are initial conditions for the stocks of human capital $(P Y R+S Y R+0)$ and demographic structure $(P O P 15+0, P O P 65+0)$.

The results are striking-conditional convergence operates at about $1.6 \%$ per annum, and, of the controls, only the set of distortion measures matter in a significant way-and, of those, tariffs have minimal import. This characterization is true in terms of statistical significance and in terms of the more important quantitative significance

43 These patterns also obtain for the Latin American and Asia-Pacific group of countries in Regressions 5-8; even in this small sample, unconditional divergence is the norm, until allowance is made for the Sachs-Warner criteria-once again the problem is "fixed" and the group shows convergence ceteris paribus for qualifiers and non qualifiers (around $1.8 \%$ per annum).

44 Estimation is by OLS for this unbalanced panel.

45 On the politics-growth nexus; see, for example. (Alesina, et al. 1992; Barro 1994). 
revealed by the ANOVA sums of squares. By the latter criteria the measure of our ignorance is large, a residual sum of squares equal to 0.185 out of a total of 0.269 . Of the explained part, the first order contributions derive from the conditional convergence effect $(L N Y O)$ and distortions (BMPL, G, GXR), each around 0.010 . Other effects are an order of magnitude smaller, or smaller still.

\section{Growth determinants and conditional convergence: structural estimation}

Thus, taken at face value, the results offer little support for claims that a principal trade distortion like tariffs retard growth, or that financial development enhances growth, or that resource endowments may lead to dynamic comparative disadvantage. Such a perspective, is, I will argue, flawed. In many ways, the reduced form Regression 7 gets us only marginally closer to an answer to the problem of "why growth rates differ" than did Regressions 1-6. For although it suggests that distortions matter, we want to know how they matter. That is a structural question-it asks how the environmental and state variables affect evolution: how the behavioral equations shift in response to perturbation. We need to ask how environment affects accumulation, investment, population growth. We also need to know whether our exogeneity assumptions are justified in estimating ( $3 a$ ). This demands an estimation of structural growth with care being taken to allow for simultaneity.

Table 8 presents structural "growth accounting" regressions, which naïvely estimate (la) for physical and human capital inputs $(P+S, C I)$ and population growth $(G P O P)$, with only a catch-up term $(L N Y O)$. We expect the first two variables to enhance growth, the latter two to repress it. The subsequent regressions in Table 8 confront a number of related hypotheses. Regression 13 replicates findings which suggest that foreign direct investment has a much higher social rate of return than other forms of investment. Regression 14 warns that this result is highly sensitive to sample selectionit disappears when Botswana and Singapore are dropped from the sample. ${ }^{46}$ Clearly, this hypothesis warrants further scrutiny.

Regressions 15-17 reintroduce controls and sample splits to allow for the political and openness qualifying variables $(O N Q P N Q)$ to play a role here. The results are broadly supportive of the basic points: investment in physical capital has a return of about $15 \%-17 \%$, though possibly lower in richer (qualifying) countries, as we might expect in a simple growth model (the rich got rich, in part, by exploiting and dissipating those returns). Population growth congests resources and has a negative effect of growth-though less in the case of richer countries, suggesting there a more

46 On foreign direct investment see Borensztein et al. (1995) and De Gregorio (1992). On Botswana and Singapore, note that these same two countries are almost always investment and growth extreme points, with high leverage in many regressions of this type, leading to problems of inference and some controversy when investment was disaggregated another way, machines versus non-machines (Auerbach 1994; De Long and Summers 1993; De Long and Summers 1991). Singapore is noted as an unusual high-investment case (Young 1992; 1994; 1993). 
elastic supply of technology, perhaps, to help overcome Malthusian pressures. Of the qualifying variables, again $O N Q$ appears to matter more (2\% per annum growth cost) than $P N Q$ ( $1 \%$ growth cost).

Where are we now? We have a reduced form suggesting that distortions are major environmental determinants of growth. And we know from the structural growth equation that factor accumulation matters for growth. Could that be the channel through which distortions operate? An augmented structural equation is helpful, as in Table 9, Regression 18. Here environmental controls are added to (la), or, equivalently, endogenous accumulation variables are added to the structure of (3a) as seen in Table 7, Regression 7. In Regression 19, I even admit explicit endogeneity, including some of the distortion and environment variables we might expect to be codetermined, e.g. financial development ( $L L Y)$, black-market premia $(B M P L)$ and the price of capital (LNPIPY). ${ }^{47}$ In the end this mattered little, because a specification test rejects 19 in favor of 18 ; this is no surprise since the fit of 19 is so much worseasymptotic gains of the 2SLS estimator are not seen in these small samples, and the efficient estimator is OLS; simultaneity bias appears insignificant using the standard Hausman test. ${ }^{48}$

What do the results reveal? Regression 18 contrasts with Regression 7 in that the admitted controls $C I$ and GPOP are significant; and in that $L N P I P Y$ is no longer significant. This result suggests that the LNPIPY distortion may indeed act via an endogenous channel, most likely through investment demand. The distortioninvestment-growth nexus is again highlighted. ${ }^{49}$ The question now remains-how does that channel work? And are there other important channels by which the environment affects putatively endogenous variables such as those just considered? Which are the key distortions from a statistical standpoint? And, quantitatively, can they explain divergent performance within and outside Latin America?

\section{Growth determinants: behavioral equation estimation}

Only a structural estimation of growth determinants as in (2a) can hope to answer such questions and Table 10 tries to do just that. Regression 20-25 estimate the "behavioral equations" for the proximate determinants of six endogenous variables in the system (CI,GPOP, $P+S, B M P L, L L Y, L N P I P Y)$. The first three regressions can then be coupled with information on the marginal contribution to growth of the various

47 As instruments I use the lagged initial values (1965-69) of the endogenous variables. These are "good" instruments to the extent that the explanators have more persistence across time than does the explicandum, the rate of growth itself, which seems to be the case: see (Easterly, et al. 1993).

48 In this test, residuals from the first stage of 2 SLS are included in the OLS specification and tested for significance; see (Pindyck and Rubinfeld 1981, pp. 303-4). Endogenous variables so treated are denoted with a dagger $(\dagger)$ in the tables.

49 This strengthens other research findings (Agarwala 1983; Barro 1991; De Long and Summers 1991; Jones 1992; Taylor 1992; 1994c). 
factor inputs (Regression 15) to help us identify what made Latin America such a slowgrowth area. ${ }^{50}$

Investment: Regression 20 pinpoints some key determinants of investment. ${ }^{51}$ The coefficient of $L N Y O$ is negative: richer countries would be expected to have high capital intensity and lower marginal product of capital in the standard growth model, hence less investment. A higher initial stock of human capital $P Y R+S Y R+O$ also discourages further accumulation, as might be expected with unbalanced growth paths in the twosector models of growth. Children constitute a major investments drag, consistent with a labor supply on investment demand via $P O P 15+0$. The aged pose no such threat via $P O P 65+0$. The size of government $(G)$ per se does not lower investment, but all other distortions do, including $B M P L, O W T I, G X R$, and most emphatically $L N P I P Y$, the price of capital, as expected. A poor financial system (small $L L Y$ ) inhibits capital accumulation significantly, as expected if intermediation and efficiency are inhibited in the capital market. A natural resource comparative advantage ( $P N X I$ high) inhibits investment, as would be the case if primary product manufacture were less capital intense. Physical capital accumulation also rises to complement rapid human capital accumulation $(P+S)$ and to offset capital dilution via high population growth rates (GPOP).

Population growth: Regression 21 explores the determinants of population growth. ${ }^{52}$ The results are consistent with the view that fertility choice may embody elements of a quality-quantity trade-off, in that population growth seems to be negatively correlated with human capital stocks and flows. This is suggestive of possible multiple equilibria consistent with high- and low-human capital development paths. ${ }^{53}$ Interestingly, population growth does seem to be positively associated with natural resource endowments $(P N X I)$, which would be consistent with theories of agricultural labor supply within the household, and also theories of saving (asset accumulation) via investment in children.

50 All six of these regressions were estimated with 2SLS, and Hausman simultaneity tests were enployed to eliminate all except the significantly endogenous right-hand side variables (denoted $\dagger$ ). The fit in all cases is quite respectable (only the last equation has an $R^{2}$ below .5, and that is .29).

51 Investment is a proxy for capital accumulation. In growth empirics, the variable has repeatedly been found to have a significant positive association with growth. Its coefficient measures the rate of return to capital, typically 10\%-20\% per annum (Kormendi and Meguire 1985; Barro 1991; Brander and Dowrick 1994; De Long and Summers 1991; Mankiw, Romer and Weil 1992). This is one of the most robust results in the entire literature (Levine and Renelt 1992).

52 The growth rate (rate of change of natural $\log$ ) of population is expected to have a negative impact on growth via capital dilution, congestion of fixed factors (diminishing returns in nonaccumulable inputs), or congestion externalities. In various empirical studies, the population effect may appear as the population growth rate as here, or sometimes as the fertility rate (Barro 1991; Brander and Dowrick 1994: Dowrick and Nguyen 1989; Kormendi and Meguire 1985; Levine and Renelt 1992; Mankiw. Romer and Weil 1992).

53 See Becker et al. (1990). 
Human capital accumulation: Regression 22 reinforces support for the qualityquantity trade-off, in that GPOP is negatively correlated with human capital accumulation measured by enrollments $(P+S)$. A large share of children in the population is associated with high enrollments too, as expected. Rich countries (high $L N Y O$ ) have higher enrollments too, again suggesting multiple-equilibria possibilities. In a rare positive impact, high government spending $G$ does spill over into economic growth to the extent that it promotes human capital accumulation. Human capital accumulation $P+S$ complements investment $C I$, just as vice versa (see above).

Black-market premium: Regression 23 examines the determinants of the blackmarket premium (BMPL). ${ }^{54}$ In keeping with our characterization of $B M P L$ as not directly tied to commercial policy, tariffs $(O W T I)$ have little impact on $B M P L$. However, $B M P L$ is associated with big government $(G)$ and, most robustly of all, with monetary instability $(G X R)$. Both seem highly plausible; to the extent that big government is associated with intervention in the form of currency controls or other distortions in the financial system, and to the extent that exchange risk is driven by expectations of devaluation of the currency, both variables should have predictive power for the blackmarket premium.

Financial depth: Regression 24 investigates the determinants of financial depth measured by $L L Y .{ }^{55}$ Financial development is associated with high incomes ( $L N Y O$ )possibly reflecting a demand for financial services as a normal good. It is also readily apparent that increased investment $(C I)$, an activity which is largely predicated on financial intermediation, is strongly associated with increased financial depth. A more educated population $(P Y R+S Y R+O)$ appears to require fewer financial services, ceteris paribus, perhaps reflecting more sophistication on the part of the consumers of financial products. Trade policy seems to matter, in that tariffs $(O W T I)$ are associated with reduced financial depth. ${ }^{56}$ There appears to be a negative association between monetary instability measured by $G X R$ and financial depth, as might be expected given

54 BMPL is a price distortion likely to have dynamic effects to the extent that it lowers investment by raising the price of (imported) capital goods, and to the extent that it impairs financial intermediation and the capital market efficiency more generally (Barro and Sala-i-Martin 1995, chap. 12). However, it has different properties than the relative price of capital, being less linked to "real" distortions such as tariffs, and more linked to monetary distortions such as exchange controls, exchange risk, inflation risk or other forms of financial repression.

55 Financial development is expected to have positive effects of lower transactions costs and enhanced allocative efficiency in the capital market, and hence to promote accumulation and growth (Davis 1963; Gurley and Shaw 1955; McKinnon 1973; Shaw 1973). Such insights can be readily incorporated in endogenous growth models (Bencivenga and Smith 1991; Greenwood and Jovanovic 1990). Recent empirical work has sought to capture these effects (King and Levine 1993b; 1993a). The variable used here follows King and Levine; an alternative measure, the reserve ratio, was used by Roubini and Sala-i-Martin (1992).

56 It is not clear what the mechanism might be, except to say that throughout economic history financial development has almost always flourished first amongst the mercantile and commercial sectors of any economy, so that a dynamic effect of trade on financial development seems plausible. 
the increased risk in financial markets. Countries with comparative advantage in primary products $(P N X I)$ appear to have lower financial depth, which seems intuitively obvious-much saving and investment in agriculture and other primary sectors is outside the scope of financial intermediaries, taking the form of land improvement, changes in stocks. In addition, the fertility choice issues noted above imply the possibility of children as an asset-accumulation choice in the quantity-quality fertility trade-off: children as assets may substitute for financial assets and intermediation.

Relative price of capital: Regression 25, finally, examines the determinants of the relative price of capital, seen to be such a vital determinant of investment demand in Regression 17.57 As expected, LNPIPY is associated with the presence of distortions at various points in the economy. About one quarter of any tariff-rate change passes through into relative investment prices, which is unsurprising in that a large share of contemporary investment is in the form of tradable machinery and equipment. About one sixth of any change in the black-market premium also passes through to LNPIPY. The most robust association, however, is between the broad measure of public finance distortions $(G)$ and the investment price, suggesting that beyond trade and the blackmarket premium, distortions and government interventions at many levels in the economy are associated with higher investment prices.

\section{Openness and growth in Latin America: A New Perspective}

Table 10 confirms our intuition regarding some of the channels by which environmental variables affect each other and affect economic growth performance. Hypothesis tests suggest significant interaction between measures of openness and other distortions and highly proximate determinants of growth such as factor accumulation. Yet if these forces matter, how much do they matter? I return to the questions which motivatedthe study, seeking to explain the divergent development path of Latin America. I go beyond the reduced-form findings which tell us that distortions matter for growth. In Table 11 I use knowledge of the structural parameters estimated above (Tables 9 and 10) with information on the differences in variables and parameters to try to explain why growth environments differ.

Summary statistics in Panel (a) indicate the basis for two comparisons: between two regions, Latin America and Asia Pacific; and withing the former, the Southern Cone versus the rest. Some immediate differences are apparent: the Asia Pacific region enjoyed much higher rates of investment $(C I)$ and human capital accumulation $(P+S)$,

$57 \mathrm{LNPIPY}$ is expected to be lower in more open economies with freely traded capital goods, and should have negative impact on investment activity and, hence, on growth. The robust negative correlation of investment prices and quantities has been seen as confirmation of a downward-sloping investment demand curve, and as the likely channel through which many price distortions affect growth (Brander and Dowrick 1994; Taylor 1994a; Taylor 1994c; Jones 1992). The inpact of distortions on conomic growth is widely reported (Agarwala 1983; Easterly 1993; Edwards 1992; Edwards 1993). On robustness see Levine and Renelt (1992). 
and lower rates of population growth (GPOP): all favorable growth traits. In addition, Asia-Pacific enjoyed the lower distortions already noted (Table 5). In Panel (b) I explore whether the regression estimates can explain the differences. Predictions are based on varaible differences multiplied by regression coefficients for each equation. The results are satisfying. Latin America grew about 3\% per annum slower, and this difference is adequately explained by structural shifts in the growth equation. Unfavorable distortions and patterns of factor accumulation lay behind this shift (final column), confirming he reduced-form analysis. Of greater interest are the six columns describing the shift in the mechanics of growth between the two samples. Investment (CI) was about 7 percentage points lower in Latin America (16\% versus 23\%), a gap explained principally by a relatively high-dependency rate (labor-supply effects via $P O P 15+0$ and POP65+0), higher distortions (BMPL,OWTI, LNPIPY), lower levels of financial development $(L L Y)$, and slower complementary human capital accumulation $(P+S)$. This is a rich description of obstacle to accumulation which highlights the many interactions at work, not just distortions. Faster population growth (GPOP) of $0.6 \%$ per annum appears to be associated primarily with a human capital interaction suggestive of an adverse choice in the quantity-quality trade off in family size. Slower human capital accumulation $(P+S$ at 1.32 versus 1.51$)$ reflected the symmetry of that same relationship, although offset in part by the youth component of the dependency rate that was harmful for physical capital accumulation.

Beyond factor accumulation patterns, I also tried to explain differences in some probably-endogenous distortion measures. Higher black-market premia (BMPL at $26 \%$ versus $6 \%$ ) followed principally from unstable exchange rates, that is, from profligate monetary policies (depreciation rates of $37 \%$ versus $2 \%$ per annum). The weaker "financial depth" ( $L L Y$ at 0.26 versus 0.55 ) derived in part from the same monetary instability (perhaps via risk disincentives), yet also from weak investment demand, suggesting a symbiotic supply-and-demand relationship between the financial sector (mobilization) and the saving-investment nexus itself (accumulaion). Lastly, the investment-goods price distortion ( $L N P I P Y$ at $26 \%$ versus $22 \%$ ) is not much different between the two regions on average, is over-explained by some margin, and appears to be driven by black-market premia and tariffs, perhaps through the traded capitalgoods channel, aided by general fiscal distortions and adverse comparative advantage in resources.

My modeling thus points to significant interactions between distortions and factor accumulation, all of which explain structural differences in the mechanics of economic growth in Latin America versus its standard counterpoint, the Asia-Pacific region. Much of the adverse relative economic performance of Latin America during 1970-90 can be so explained. Of course, the model may be pushed too far. This happens in Panel (c), where I try to use it for within-sample predicted on Latin America alone, for the Southern Cone subset versus the rest. The model performs 
poorly, though this may not be surprising-as already noted (Table 5), the Southern Cone suffered greater distortions, but not appreciably worse growth outcomes. Panel (c) suggests a tentative reason why: actual investment levels in the Southern Cone were much higher than predicted. They should have been 3 points lower than in the rest of the region, but ended up 1 point higher. This helps explain why the growth prediction $(G Y)$ is out by almost $2 \%$ per annum. All other predictions (GPOP, $P+S, B M P L, L L Y$, $L N P I P Y)$ were of the right sign, and reasonably accurate except for $L N P I P Y$ : which was higher than predicted in the Southern Cone. That is, despite higher relative prices for capital, and worse distortions in other respects, the Cone maintained better than expected investment and, hence, growth performance relative to the rest of the region.

By implication, miserable as growth was in Argentina and her neighbors, it could have been worse. What is going on here? I provide one conjecture: the Southern Cone group of countries embraced ISI with the most enthusiasm, and in this group the vestiges of ISI persisted longer. As already noted, ISI strategy rested on promoting capital-intensize manufacturing and using multiple tariff and exchange-rate policies to raise effective protection far above nominal levels for key sectors. Thus it should come as no surprise that investment was unusually high in these cases, at least relative to a prediction built around macro-indices of protection. ${ }^{58}$ Ironically, it seems, we have found a redeeming feature in ISI, a mild basis for rehabilitation: ISI distorted the economy, but, by promoting manufacturing, the growth impact was not as severe as it could have been. It, may, however, be suggestive of allocative efficiencies being captured in a static sense, or dynamic manfacturing externalities being captured, perhaps offsetting the Southern Cone's comparative advantage in natural resources, following the arguments of Sachs and Warner (1994). On the final cost-benefit balance sheet, the classic "big push" of the ISI strategy in Latin America may thus have had investment-driven pluses, even if, viewed in global perspective, they were small relative to its many minuses. The strategy worked well, say, compared to a big push into guano, or some other sector with less than hopeful long-run growth prospects. Still, ISI was by no means defensible as a "first-best" (or, rather, "not worst") policy choice even on these grounds.

\section{Conclusion}

From the 1930s to the 1980s, economic policies in Latin America epitomized the inward-looking model of economic development. The model was born of the experience of a peripheral region in the Depression, and codified by the 1950s in unorthodox economic theories. Even though its performance in the shape of the ISI strategy was seen as disappointing by the 1960s, and its narrow strictures were often

58 To fathom the extent of multifarious distortions and the incentives to accumulate so unusually last would require us to explore ERP data econometrically (the data is scarce) or use general equilibrium analysis in a multisector model, a potentially profitable exercise for case studies of individual countries. 
ignored for practical purposes, the distortions created by the autarkic policy regime were long lived, persisting, and indeed worsening, relative to the rest of the world, in the 1970s and 1980s.

I attempted to examine the mechanics of economic growth in Latin America and elsewhere. Some features of my empirical approach stand out from previous work. By a determined effort to invoke structural analysis I seek to offset the rapidly diminishing returns to the now familiar and repetitive reduced-form growth regressions. We have no dearth of growth theories, but in their great variety they suggest a multitude of channels through which growth is affected by environmental variables, including policy, demographics, distortions, and the like. The empirical challenge is now to get deeper into the workings of the growth process itself and identify which mechanisms operate, how, when, and where. Such a course will, of course, take us only so far, and much lies beyond the scope of aggregative empirical models-considerations of structural change, comparative advantage, and the microeconomics of household or institutional choice in matters of, say, fertility, finance, research, or education.

Notwithstanding the ultimate constraints on the macroeconomic methodology, this paper invites us to consider some of the still unexplored dimensions of growth and its determinants. To illustrate the possibilities, I chose the canonical contrast of development "failure" in a region in the late twentieth century, Latin America, set against the undisputed "success" case, the Asia Pacific region. I found a rich set of interactions between policy, distortions, accumulation and growth. Overall, the structural approach explained almost exactly all of the difference in growth rates between the two regions, a rather large 3 percent per annum, and the greater part of this derived from differences in investment in physical capital accumulation. ${ }^{59}$ There were still puzzles, however: strangely, the Southern Cone did better than predicted within its region, despite high distortions. It is a matter for further research to determine whether this was mere good luck, a better tailoring of ISI to that region's needs, or an actual case of a successful "big push" strategy which offset in part the otherwise disastrous economic consequences of inward-looking development; poor as economic growth was in the Southern Cone it would be predicted to have been even worse.

There can always be further qualifications to the extent that other omitted or unmeasurable variables remain outside the scope of the study, and one can immediately enumerate several important caveats. We could certainly benefit from more disaggregative measures of relative prices to distinguish between tradable (exogenous) and non-tradable (tradable) capital goods: yet work on investment

59 Relative to the pooled sample, we have, then effectively reduced the explanatory role of the "regional (Asia or Latin America) dummy variable" so often used to mop up residual regional differences in growth regressions. Indeed, explaining this much variation in growth rates across the regions uithout a dummy can be secn as an empirical accomplishment, (The World Bank 1993). 
disaggregation remains contentious and has raised questions about our capability to effectively disaggregate the data in less-developed countries with poor data quality. ${ }^{60}$ On another dimension, it might be objected that the differential impact of the debt crisis within and beyond Latin America had some explanatory power, though my analysis went through for a sample period 1970-1989, before and after the onset of serious debt overhangs. Another quibble might be that the supposedly open AsiaPacific region had its own forms of government intervention to promote exports and that these policies were distortionary and good for growth, whilst being far from a natural definition of "openness"; however, microeconomic work cast doubts on this claim. ${ }^{61}$ Certainly, the results within Latin America caution that the policy variables cannot explain everything, and the approach as a whole invites application and extension to other periods and samples as a means to investigate its robustness.

However, the results of the present study offer a more nuanced view of growth, one where the structural aspects of accumulation dynamics are elevated to center stage. We encounter yet again the most robust of results in the growth literature, the strong relationship between investment and economic growth. ${ }^{62}$ We also see the important linkages, a step further removed, between investment and the economic environment. Here, in the broader comparisons, the message was clear: distortions were costly for accumulation and growth and could, in large part, explain divergent development in Latin America.

60 For a disaggregative approach to investment see the work of De Long and Summers (De Long 1988; De Long and Summers 1991; De Long 1992; De Long and Summers 1993); this work has been subject to recent criticisin (Auerbach 1994).

61 One recent sectoral study suggests that even the supposedly beneficial and well-intentioned government interventions which comprised Korean industrial policy after the 1960s had adverse or zero effects, and that free trade would have been a better alternative (Lee 1995).

62 Curiously, one major study finds almost no association between growth and investment when treating the latter as endogenous, namely (Barro and Sala-i-Martin 1995 chapter 12),. The result derives, it would appear, in a pseudo-reduced form or hybrid regression, a mixing of forms (la) and (2a). It is not clear which are direct effects of environmental variables on growth, and which operate via the investment channel. If misspecified, variables from the investment equation placed in the growth equation may take on unwarranted quantitative and statistical significance at the expense of the investment term 


\section{DATA APPENDIX}

Sources are indicated at the end of each item as follows:

BL Barro, R. J., and J.-W. Lee. "Data Set for a Panel of 138 Countries." National Bureau of Economic Research, Cambridge, Mass., January 1994. Internet $<$ http://nber.harvard.edu $>$.

PWT Heston, A. et al. "The Penn World Table, Version 5.6." National Bureau of Economic Research, Cambridge, Mass., November 1994. Internet $<$ http://nber.harvard.edu $>$.

SW Sachs, J. D., and A. M. Warner. "Economic Convergence and Economic Policies." Working Paper Series no. 5039, National Bureau of Economic Research, February 1995.

WD The World Bank. World Data 1994: World Bank Indicators on CD-ROM. Washington, D.C.: The World Bank, 1994.

\section{A.1. State variables}

\section{A.1.1. DEPENDENT VARIABLE}

GY: The growth rate (rate of change of natural log) of per capita GDP in purchasing power parity units. The standard variable chosen as the explicandum in most empirical growth studies, and viewed as a function of changes in endowments and production technology. However, it is also true that several studies have focused on alternative dependent variables, notably real output per worker or worker-hour (Maddison 1982; 1989; 1991), and real wages (Williamson 1995). PWT.

\section{A.1.2. INDEPENDENT VARIABLES-INITIAL CONDITIONS}

LNYO: $\quad$ The natural log of initial GDP per capita. Expected to influence growth if convergence forces operate, either directly or indirectly (via accumulation). Such effects can be a manifestation of the advantages of backwardness and a cause of technological catching-up (Abramovitz 1986; Gerschenkron 1962). A negative coefficient implies a form of mean reversion in the sample, and has been termed $\beta$-convergence (Barro and Sala-i-Martin 1992). $\beta$-convergence is neither a necessary nor sufficient condition for $\sigma$-convergence, the tendency of sample dispersion to diminish. The classic example of this is Galton's fallacy, invoked as a cautionary tale concerning the implications of cross-country growth regressions for the leveling of the distribution of cross-country income levels (Friedman 1992; Quah 1993). Thus regressions may say something about growth determinants, but to the extent that they omit shocks and propagations which also affect the cross-section distribution, they tell only a partial story: an analysis of $\sigma$-convergence patterns should complement the analysis. The $\beta$ convergence hypothesis is also problematic-sample selection bias and errors in-variables can encourage false acceptance (Abramovitz 1986; De Long 1988). PWT.

$P Y R+S Y R+O:$ Initial years of primary and secondary schooling per person in the population. A proxy for the initial stock of human capital in the economy. Several models 
suggest that transitional dynamics along trajectories depend critically on the initial endowments of physical and human capital (Barro and Sala-i-Martin 1995, chap. 5; Mulligan and Sala-i-Martin 1993; Caballe and Santos 1993; Lucas 1988; Uzawa 1965). Numerous authors have introduced controls of this form in empirical studies of conditional convergence (Barro 1991; Barro and Sala-i-Martin 1995, chap. 12: Mankiw, Romer and Weil 1992). Measurement problems are serious. The international comparison of schooling is fraught with quality incomparabilities. These are probably most serious for tertiary education data, omitted here, but still problematic for secondary and primary data. Alternative indirect measures based on earnings may be useful (Mulligan and Sala-i-Martin 1995). The latest attempt to create a cross-country database of human capital statistics was by Barro and Lee (1993). Besides years of schooling and enrollment rates, an alternative human capital measure sometimes used is the literacy rate (Barro 1991). BL.

\section{A.2. Endogenous control variables}

\section{A.2.1. FACTOR ACCUMULATION}

$P+S: \quad$ The average enrollment rate in primary and secondary schools. A proxy for human capital accumulation, expected to have a positive impact on growth. The caveats applied to the measurement of initial stocks of human capital also apply here. Note that there has been some variation in the literature concerning the appropriate use and interpretation of enrollment rates versus schooling stocks in growth regressions, analogous to their representing proxies for accumulation or initial conditions (Barro 1991; Mankiw, Romer and Weil 1992). BL.

C1: The ratio of real gross investment to real GDP at constant international prices. A proxy for capital accumulation, and expected to have a positive impact on growth through capital deepening and embodied new technology. In structural estimates of growth determinants, the total investment share of output variable has repeatedly been found to have a significant positive association with growth. Its coefficient measures the rate of return to capital, and is typically around 10\%-20\% per annum (Kormendi and Meguire, 1985; Barro, 1991; De Long and Summers, 1991; Mankiw, Romer and Weil, 1992; Brander and Dowrick, 1994). This is one of the most robust results in the entire literature (Levine and Renelt, 1992). PWT.

GPOP: $\quad$ The growth rate (rate of change of natural log) of population, expected to have a negative impact on growth via capital dilution, congestion of fixed factors (diminishing returns in non-accumulable inputs), or congestion externalities. By definition this variable is the sum of the rate of natural increase and the net immigration rate, both of which may be modeled as endogenous variables. Models of the structural equation of migration usually posit a positive relation between level of income per capita (or wages) and the rate of immigration, usually subject to transportation and adjustment costs. Models of fertility choice may have a nonmonotonic relationship depending on the opportunity costs of children and their value as "normal goods" (Barro and Sala-i-Martin 1995, chap. 9); interactions with human capital accumulation may also give rise to multiple 
FDIXY: The ratio of foreign direct investment going into the country (capital account credits) to GDP. Expected to affect growth positively if inbound FDI embodies the catching-up process of technology transfer from rich (high productivity) to poor (low-productivity) countries. Several authors have suggested that FDI may be an important mechanism for technology transfer, and hence catching up. These ideas can be incorporated into complex models of learning and knowledge diffusion. De Gregorio and others have proposed using FDI data to capture this effect (Borensztein, De Gregorio and Lee 1995; De Gregorio 1992; Findlay 1978; Grossman and Helpman 1991; Jovanovic and Rob 1989; Romer 1990; Romer 1993; Segerstrom 1991). WD.

\section{A.3. Environmental variables}

\section{A.3.1. NATURAL RESOURCE ENDOWMENTS}

$P N X I$ : A measure of primary product net export intensity (ratio of primary product net exports to GDP). In a Heckscher-Ohlin-Vanek sense, measures the relative abundance of natural resources embodied in primary products in any country relative to the world resource endowment. May affect growth via dynamic comparative advantage. The use of a control for resource abundance is suggested by Sachs and Warner $(1994 ; 1995)$. Their measure differs in that they use gross exports (not net), and normalize relative to total exports (not GDP). Dynamic comparative advantage suggests that learning-by-doing or other externalities may give growth and welfare advantages to countries which specialize in manufacturing because of protection or natural autarky, or by dint of endowments or scale (Ethier 1982; Krugman 1987; Young 1991). This idea has been formalized in a model of growth and industrialization by Matsuyama (1992). WD.

\section{A.3.2. DEMOGRAPHIC STRUCTURE}

POP $x x+O)$ Initial share of population aged under $15(\mathrm{xx}=15)$, over $65(\mathrm{xx}=65)$. A control for the initial denographic structure of the economy. May have dynamic growth effects if demography affects investment or human capital accumulation. On the labor supply effect, there is a robust cross-country partial correlation between the "labor content" of the population (e.g., share aged 1564) and investment ratios, even after controlling for price distortions and other determinants of investment (Brander and Dowrick 1994; Taylor 1994a). PWT.

\section{A.3.3. GOVERNMENT AND POLITICS}

C: The share of government spending in GDP at current domestic prices. A proxy for the size of government, and hence overall tax rates. Both the activity of government and the public finance distortions might have adverse growth effects. The best known model is that of Barro, which has some empirical 
support (Barro 1990; 1991). Other studies have considered measuring the impact of fiscal policy on growth in a number of ways. However, the overall evidence is mixed. The association of fiscal variables and growth, both direct and via the investment channel, remains fragile (Easterly and Rebelo 1993; Levine and Renelt 1992). PWT.

PNQ: $\quad$ Political non-qualifier country in the Sachs-Warner (1995) classification. A country fails the test $(P N Q=1)$ if it has a socialist economic structure, suffers from extreme domestic unrest, or is characterized by extreme deprivation of civil or political rights. The variable is time-invariant 1970-89 for each country. Political variables have been constructed and widely used by Barro and his collaborators (Barro, 1991; Barro and Lee, 1994; Barro and Sala-i-Martin, 1995). However, the significance and robustness of their role as explanators of growth performance remains controversial (Levine and Renelt, 1992). Political variables may not be exogenous, however: Alesina et al. (1992) explore political instability as an endogenous variable simultaneously determined with economic performance. SW.

\section{A.3.4. PRICE DISTORTIONS AND OPENNESS}

LNPIPY: $\quad$ The relative price of capital goods, calculated as the natural log of the ratio of the PPP for investment to the PPP for GDP. The PPPs are relative to the U.S. Expected to be lower in more open economies with freely traded capital goods. Expected to have negative impact on investment activity and, hence, on growth. The robust negative correlation of investment prices and quantities has been seen as confirmation of a downward-sloping investment demand curve, and as the likely channel through which many price distortions affect growth (Jones, 1992; Brander and Dowrick, 1994; Taylor, 1994a; Taylor, 1994b). The impact of distortions on economic growth is widely reported (Agarwala, 1983; Edwards, 1992; Easterly, 1993; Edwards, 1993). The fact that measures of trade policy including such distortionary effects are not significant growth determinants when the investment share is included in any specification reinforces our suspicion that endogenous investment response is indeed the principal channel (Levine and Renelt 1992). Unfortunately the misspecification of price distortions of this kind is common: too often a variable PPI or PPIDEV is misused, based on the natural log of the Heston-Summers investment PPP. Such use of absolute prices like PPI dates back to Barro (1991), but has been widespread. These are absolute price levels. As Higgins (1993) has pointed out, what matters for investment is the holding return on capital, which is a function of the price of investment relative to output, as in the present paper. The point is general, and also applies to foreign investment with the addition of exchange-rate risk. PWT.

BMPL: $\quad$ The natural log of one plus the black-market premium on the exchange rate for the currency. A price distortion likely to have dynamic effects to the extent that it lowers investment by raising the price of (imported) capital goods, and to the extent that it impairs financial intermediation and the capital market efficiency more generally. This is an alternative price distortion variable also used in empirical growth analysis (Barro and Sala-i-Martin, 1995, chap. 12). 
OWTI: Own-weight tariff incidence, a measure of average tariff rates in the economy. The variable is time-invariant 1970-89 for each country. Based on UNCTAD data from a 1988 cross-section. Another price distortion likely to have dynamic effects should it apply to imported capital goods, raising prices and creating disincentives for investment. Yet another measure of price distortions, which might plausibly affect the relative price of capital, and hence investment, as noted above (Barro and Sala-i-Martin 1995, chap. 12; Jones 1992). BL.

$O N Q: \quad O p e n n e s s$ non-qualifier country in the Sachs-Warner (1995) classification. A country fails the test $(O N Q=1)$ if it has high quota incidence on imports, a high proportion of exports handled by state export monopolies, a socialist economic structure, or has a black-market premium above $20 \%$ on average in the $1970 \mathrm{~s}$ or 1980s. The variable is time-invariant $1970-89$ for each country. SW.

\section{A.3.5. FINANCIAL INTERMEDIATION AND MONETARY INSTABILITY}

$G X R: \quad$ The rate of depreciation of the currency, measured as the growth rate (rate of change of the natural log) of the exchange rate in currency units per U.S. dollar. A proxy for monetary instability, which might affect growth negatively through instability and risk costs of intermediation felt in the capital market. Other studies have used the rate of domestic inflation as a proxy for monetary instability and financial repression (De Gregorio 1992; Kormendi and Meguire 1985; Roubini and Sala-i-Martin 1992). The choice of exchange-rate growth or inflation are equivalent in the longer run when purchasing power parity holds beyond short-run deviations; current research suggests a "short" four-year half life for PPP deviations (Frankel and Rose 1995; Taylor 1995). PWT.

$L L Y: \quad$ The ratio of liquid liabilities in the financial system to GDP. A proxy for the size of the financial sector, and a measure of financial development. Expected to have positive effects of lower transactions costs and enhanced allocative efficiency in the capital market, and hence to promote accumulation and growth. Various authors have stressed the importance of financial intermediation for growth-separating the problem of capital accumulation from the problem of capital mobilization and allocation (Gurley and Shaw, 1955; Davis, 1963; McKinnon, 1973; Shaw, 1973). Such insights can be readily incorporated into endogenous growth models (Greenwood and Jovanovic, 1990; Bencivenga and Smith, 1991). Recent empirical work has sought to capture these effects (King and Levine, 1993b; 1993a). The variable used here follows King and Levine; an alternative measure of financial development, the reserve ratio, has also been tried (Roubini and Sala-i-Martin 1992). BL. 


\section{REFERENCES}

Abramovitz, M. 1956. Resource and Output Trends in the United States Since 1870. American Economir Revieu 46 (May): 5-23.

Abramovitz, M. 1986. Catching Up, Forging Ahead, and Falling Behind. Journal of Economic History 46 (June): $385-406$.

Agarwala, R. 1983. Price Distortions and Growth in Developing Countries. World Bank Staff Working Paper no. 575, Washington, D.C.

Alesina, A. et al. 1992. Political Instability and Economic Growth. Working Paper Series no. 4173, National Bureau of Economic Research.

Auerbach, A. J. 1994. Reassessing the Social Returns to Equipment Investment. Quarterly Journal of Economics 109 (August): 789-802.

Bairoch, P., and M. Lévy-Leboyer, ed. 1981. Disparities in Economic Development Since the Industrial Revolution. Basingstoke: Macmillan.

Barro, R. J. 1990. Government Spending in a Simple Model of Endogenous Growth. Journal of Political Economy 98 (October): S103-25.

Barro, R. J. 1991. Economic Growth in a Cross Section of Countries. Quarterly Journal of Economics 106 (May): 407-43.

Barro, R. J. 1994. Democracy and Growth. Working Paper Series no. 4909, National Bureau of Economic Research (October).

Barro, R. J., and J.-W. Lee. 1993. International Comparisons of Educational Attainment. Journal of Monetary Economics 32 : 363-94.

Barro, R. J., and J.-W. Lee. 1994. Data Set for a Panel of 138 Countries. National Bureau of Economic Research, Cambridge, Mass. (January). Internet <http://nber.harvard edu>.

Barro, R. J., and X. Sala-i-Martin. 1992. Convergence. Journal of Political Economy 100 (April): 223-52.

Barro, R. J., and X. Sala-i-Martin. 1995. Economic Growth. New York: McGraw-Hill.

Baumol, W. 1986. Productivity Growth, Convergence and Welfare: What the Long-Run Data Show. American Economic Review 76 (December): 1072-85.

Becker, G. S., and R. J. Barro. 1988. A Reformulation of the Economic Theory of Fertility. Quarterly Journal of Economics 103 (February): 1-25.

Becker, G. S., K. M. Murphy, and R. Tamura. 1990. Human Capital, Fertility, and Economic Growth. Journal of Political Economy 98 (October): S12-37.

Bencivenga, V. R., and B. D. Smith. 1991. Financial Intermediation and Endogenous Growth. Revilew of Economic Studies 58 : 195-209.

Bhagwati, J. 1984. Comment on Raúl Prebisch, Five Stages in My Thinking on Development. In Pioneers in Development, edited by G. M. Meier and D. Seers. New York: Oxford University Press.

Borensztein, E., J. De Gregorio, and J.-W. Lee. 1995. How Does Foreign Direct Investment Affect Growth? Working Paper Series no. 5057, National Bureau of Economic Research (March). 
Brander, J. A., and S. Dowrick. 1994. The Role of Fertility and Population in Economic Growth: Empirical Results from Aggregate Cross-National Data. Journal of Population Economics $7: 1-25$.

Bulmer-Thomas, V. 1994. The Economic History of Latin America Since Independence. Cambridge: Cambridge University Press.

Caballe, J., and M. S. Santos. 1993. On Endogenous Growth with Physical and Human Capital. Journal of Political Economy 101 (December): 1042-67.

Campa, J. M. 1990. Exchange Rates and Economic Recovery in the 1930s: An Extension to Latin America. Journal of Economic History 50 (September): 677-82.

Cardoso, E., and A. Helwege. 1992. Latin America's Economy: Diversity Trends and Conflicts. Cambridge, Mass.: MIT Press.

Coatsworth, J. H. 1993. Economic Retardation and Growth in Latin America and Southern Europe Since 1700. Harvard University (December). Photocopy.

Davis, L. E. 1963. Capital Immobilities and Finance Capitalism: A Study of Economic Evolution in the United States. Explorations in Economic History 1 (Fall): 88-105.

De Gregorio, J. 1992. Economic Growth in Latin America. Journal of Development Economics 39 : $59-84$.

De Long, J. B. 1988. Productivity Growth, Convergence and Welfare: Comment. American Economic Review 78 (December): 1138-54.

De Long, J. B. 1992. Productivity Growth and Machinery Investment: A Long-Run Look. Journal of Economic History 52 (June): 307-24.

De Long, J. B., and L. H. Summers. 1991. Equipment Investment and Economic Growth. Quarterly Journal of Economics 106 (May): 445-502.

De Long, J. B., and L. H. Summers. 1993. How Strongly Do Developing Economies Benefic From Equipment Investment? Journal of Monetary Economics 32 : 395-415.

Denison, E. F. 1967. Why Growth Rates Differ. Washington, D.C.: The Brookings Institution.

Díaz Alejandro, C. F. 1974. Some Characteristics of Recent Export Expansion in Latin America. In The International Division of Labor: Problems and Perspectives, edited by $\mathrm{H}$. Giersch. Tübingen: Mohr.

Díaz Alejandro, C. F. 1984a. The 1940s in Latin America. In Economic Structure and Performance: Essays in Honor of Hollis B. Chenery, edited by M. Syrquin, L. Taylor and L. E. Westphal. Orlando: Academic Press.

Díaz Alejandro, C. F. 1984b. Latin America in the 1930s. In Latin America in the 1930s: The Role of the Periphery in World Crisis, edited by R. Thorp. New York: St. Martin's Press.

Dowrick, S., and D.-T. Nguyen. 1989. OECD Comparative Economic Growth 1950-85: CatchUp and Convergence. American Economic Review 79 (December): 1010-30.

Easterly, W. 1993. How Much Do Distortions Affect Growth? Journal of Monetary Economics 32 : $187-212$.

Easterly, W. et al. 1993. Good Policy or Good Luck? Country Growth Performance and Temporary Shocks. Working Paper Series no. 4474, National Bureau of Economic Research (September).

Easterly, W., and S. Rebelo. 1993. Fiscal Policy and Economic Growth: An Empirical Investigation. Journal of Monetary Economics $32: 417-58$. 
ECLA (United Nations Economic Commission for Latin America). 1950a. The Economic Development of Latin America and Its Principal Problems. 5 vols. New York: United Nations. ECLA (United Nations Economic Commission for Latin America). 1950b. Economic Survey of Latin America, 1949. 5 vols. New York: United Nations.

Edwards, S. 1992. Trade orientation, Distortions and Growth in Developing Countries. Journal of Development Economics 39 : 31-57.

Edwards, S. 1993. Openness, Trade Liberalization and Growth in Developing Countries. Journal of Economic Literature 31 (September): 1358-93.

Eichengreen, B. J., and J. D. Sachs. 1985. Exchange Rates and Economic Recovery in the 1930s. Journal of Economic History 45 (December): 925-46.

Ethier, W. J. 1982. National and International Returns to Scale in the Modern Theory of International Trade. American Economic Review 72 (June): 389-404.

Feder, G. 1983. On Exports and Economic Growth. Journal of Development Economics 12 (February-April): 59-73.

Findlay, R. 1978. Relative Backwardness, Direct Foreign Investment, and the Transfer of Technology. Quarterly Journal of Economics 92 (February): 1-16.

Frankel, J. A., and A. K. Rose. 1995. A Panel Project on Purchasing Power Parity: Mean Reversion Within and Between Countries. Working Paper Series no. 5006, National Bureau of Economic Research (February).

Friedman, M. 1992. Do Old Fallacies Ever Die? Joumal of Economic Literature 30 (December): 2129-32.

Gerschenkron, A. 1962. Economic Backwardness in Historical Perspective. Cambridge, Mass.: Harvard University Press.

Greene, W. H. 1993. Econometric Analysis. 2nd ed. New York: Macmillan.

Greenwood, J., and B. Jovanovic. 1990. Financial Development, Growth, and the Distribution of Income. Journal of Political Economy 98 : 1076-107.

Grossman, G. M., and E. Helpman. 1991. Innovation and Growth in the Global Economy. Cambridge, Mass.: MIT Press.

Gurley, J. G., and E. S. Shaw. 1955. Financial Aspects of Economic Development. American Economic Review 45 (September): 515-38.

Heston, A. et al. 1994. The Penn World Table, Version 5.6. National Bureau of Economic Research, Cambridge, Mass. (November). Internet <http://nber.harvard.edu>.

Higgins, M. D. 1993. Why Capital Doesn't Flow From Rich to Poor Countries. Harvard University. Photocopy.

Jones, C. I. 1992. Economic Growth and the Relative Price of Capital. MIT (February). lholocopy.

Jorgenson, D. W. 1995. Productivity. 2 vols. Cambridge, Mass.: MIT Press.

Jovanovic, B., and R. Rob. 1989. The Growth and Diffusion of Knowledge. Review of Economic Studies 56 (October): 569-82.

Kay, C. 1989. Latin American Theories of Development and Underdevelopment. New York: Routledge.

King, R. G., and R. Levine. 1993a. Finance and Growth: Schumpeter Might Be Right. Quarterly Joumal of Economics 108 : 717-38. 
King, R. G., and R. Levine. 1993b. Finance, Entrepreneurship, and Growth Journal of Monetary Economics 32 : 513-42.

Kormendi, R. C., and P. G. Meguire. 1985. Macroeconomic Determinants of Growth: Cross-

Country Evidence. Journal of Monetary Economics 16 (September): 141-63.

Krugnan, P. R. 1987. The Narrow Moving Band, The Dutch Disease, and the Competitive Consequences of Mrs. Thatcher. Journal of Development Economics $27: 41-55$.

Lee, J.-W. 1995. Government Interventions and Productivity Growth in Korean Manufacturing Industries. Working Paper Series no. 5060, National Bureau of Economic Research (March).

Levine, R., and D. Renelt. 1992. A Sensitivity Analysis of Cross-Country Growth Regressions. American Economic Review 82 (September): 942-63.

Lewis, W. A. 1978. The Evolution of the International Economic Order. Princeton, N.J.: Princeton University Press.

Lucas, R. E. 1988. On the Mechanics of Economic Development. Journal of Monetary Economics 22 (July): 3-42.

Maddison, A. 1982. Phases of Capitalist Development. Oxford: Oxford University Press.

Maddison, A. 1989. The World Economy in the 20th Century. Paris: OECD.

Maddison, A. 1991. Dynamic Forces in Capitalist Development: A Long-Run Comparative Vieu. Oxford: Oxford University Press.

Mankiw, N. G., D. Romer, and D. N. Weil. 1992. A Contribution to the Empirics of Economic Growth. Quarterly Journal of Economics 107 (May): 407-37.

Matsuyama, K. 1992. Agricultural Productivity, Comparative Advantage, and Economic Growth. Journal of Economic Theory 58 : 317-34.

McKinnon, R. I. 1973. Money and Capital in Economic Development. Washington, D.C.: The Brookings Institution.

Mulligan, C. B., and X. Sala-i-Martin. 1993. Transitional Dynamics in Two-Sector Models of Endogenous Growth. Quarterly Journal of Economics 108 (August): 737-73.

Mulligan, C. B., and X. Sala-i-Martin. 1995. A Labor-Income-Based Measure of the Value of Human Capital: An Application to the States of the United States. Working Paper Series no. 5018, National Bureau of Economic Research (February).

Nurkse, R. 1961. Patterns of Trade and Development. The Wicksell Lectures Oxford: Basil Blackivell.

Palma, J. (. 1987a. Dependency. In The New Palgrave: A Dictionary of Economics, edited by J Eatwell, M. Milgate and P. Newman. New York: Stockton Press.

Palma, J. G. 1987b. Prebisch, Raúl. In The New Palgrave: A Dictionary of Economics, edited by J. Eatwell, M. Milgate and P. Newman. New York: Stockton Press.

Palma, J. G. 1987c. Structuralism. In The New Palgrave: A Dictionary of Economics, edited by J. Eatwell, M. Milgate and P. Newman. New York: Stockton Press.

Pindyck, R. S., and D. L. Rubinfeld. 1981. Econometric Models and Economic Forecasts. New York: McGraw-Hill.

Prebisch, R. 1984. Five Stages in My Thinking on Development. In Pioneers in Development, edited by G. M. Meier and D. Seers. New York: Oxford University Press. 
Quah, D. 1993. Galton's Fallacy and Tests of the Convergence Hypothesis. In Endogenous Growth, edited by T. M. Andersen and K. O. Moene. Oxford: Blackwell.

Ramsey, F. P. 1928. A Mathematical Theory of Savings. Economic Journal 38 (December): $543-$ 59.

Rebelo, S. 1991. Long-Run Policy Analysis and Long-Run Growth. Journal of Political Economy 99 (June): 500-21.

Romer, P. M. 1986. Increasing Returns and Long-Run Growth. Journal of Political Economy 94 (October): 1002-37.

Romer, P. M. 1989. Capital Accumulation in the Theory of Long-Run Growth. In Modern Business Cycle Theory, edited by R. J. Barro. Cambridge, Mass.: Harvard University Press.

Romer, P. M. 1990. Endogenous Technological Change. Journal of Political Economy 98 (October): S7 1-102.

Romer, P. M. 1993. Idea Gaps and Object Gaps in Economic Development. Journal of Monetary Economics 32 (December): 543-73.

Romer, P. M. 1994. The Origins of Endogenous Growth. Journal of Economic Perspectives 8 (Winter): 3-22.

Rosenstein-Rodan, P. N. 1943. Problems of Industrialization of Eastern and Southern Europe. Economic Journal 53 : 202-11.

Roubini, N., and X. Sala-i-Martin. 1992. Financial Repression and Economic Growth. Joumal of Development Economics $39: 5-30$.

Sachs, J. D., and A. M. Warner. 1994. Natural Resources and Economic Growth. Harvard University (August).

Sachs, J. D., and A. M. Warner. 1995. Economic Convergence and Economic Policies. Working Paper Series no. 5039, National Bureau of Economic Research (February).

Segerstrom, P. S. 1991. Innovation, Imitation, and Economic Growth. Journal of Political Economy 99 (August): 807-27.

Shaw, E. S. 1973. Financial Deepening in Economic Development. Oxford: Oxford University Press.

Singer, H. 1950. The Division of Gains Between Investing and Borrowing Countries. American Economic Reriew 40 (May): 473-80.

Solow, R. M. 1956. A Contribution to the Theory of Economic Growth. Quarterly Journal of Economics 70 (February): 65-94.

Swan, T. W. 1956. Economic Growth and Capital Accumulation. Economic Record 32 (November): 334-61.

Taylor, A. M. 1992. Argentine Economic Growth in Comparative Perspective. Ph. D. dissertation, Harvard University (July).

Taylor, A. M. 1994a. Domestic Saving and International Capital Flows Reconsidered. Working Paper Series no. 4892, National Bureau of Economic Research (October).

Taylor, A. M. 1994b. Three Phases of Argentine Economic Growth. Working Paper Series on Historical Factors in Long Run Growth no. 60, National Bureau of Economic Research (October).

Taỵlor, A. M. 1994c. Tres fases del crecimiento económico argentino. Revista de Historia Economica 12 (Fall): 649-83. 
Taylor, A. M. 1996. Growth and Convergence in the Asia-Pacific Region: On the Role of Openness, Trade and Migration. In International Trade and Migration in the Asia-Pacific Region, edited by P. J. Lloyd and L. S. Williams. Oxford: Oxford University Press.

Taylor, M. P. 1995. The Economics of Exchange Rates. Journal of Economic Literature 33 (March): 13-47.

The World Bank. 1993. The East Asian Miracle: Economic Growth and Public Policy. Oxford: Oxford University Press.

The World Bank. 1994. World Data 1994: World Bank Indicators on CD-ROM. Washington, D.C.: The World Bank.

Uzawa, H. 1965. Optimum Technical Change in an Aggregative Model of Economic Growth. International Economic Review 6 (January): 18-31.

Williamson, J. G. 1995. The Evolution of Global Labor Markets since 1830: Background Evidence and Hypotheses. Explorations in Economic History 32 (April): 141-96.

Young, A. 1991. Learning By Doing and the Dynamic Effects of International Trade. Quarterly Joumal of Economics 106 (May): 369-406.

Young, A. 1992. A Tale of Two Cities: Factor Accumulation and Technical Change in Hong Kong and Singapore. In NBER Macroeconomics Annual 1992, edited by O.J. Blanchard and S. Fischer. Cambridge, Mass.: MIT Press.

Young, A. 1993. Lessons from the East Asian NICs: A Contrarian View. Working Paper Series no. 4482, National Bureau of Economic Research (October).

Young, A. 1994. The Tyranny of Numbers: Confronting the Statistical Realities of the East Asian Growth Experience. Working Paper Series no. 4680, National Bureau of Economic Research (March). 
Table 1

Latin America's Declining Share of World Exports

\begin{tabular}{lrrrrr}
\hline \hline & $\begin{array}{l}\text { Latin } \\
\text { Anerica }\end{array}$ & $\begin{array}{r}\text { Major } \\
\text { Countries }\end{array}$ & $\begin{array}{r}\text { Other } \\
\text { Countries }\end{array}$ & Argentina & Brazil \\
\cline { 2 - 6 } 1946 & $13.5 \%$ & $8.9 \%$ & $4.6 \%$ & $3.4 \%$ & $2.9 \%$ \\
1948 & $12.1 \%$ & $7.3 \%$ & $4.8 \%$ & $3.0 \%$ & $2.2 \%$ \\
1950 & $10.7 \%$ & $6.7 \%$ & $4.0 \%$ & $2.0 \%$ & $2.3 \%$ \\
1955 & $8.9 \%$ & $4.9 \%$ & $4.0 \%$ & $1.1 \%$ & $1.6 \%$ \\
1960 & $7.0 \%$ & $3.5 \%$ & $3.5 \%$ & $0.9 \%$ & $1.1 \%$ \\
1965 & $6.2 \%$ & $3.2 \%$ & $3.0 \%$ & $0.9 \%$ & $0.9 \%$ \\
1970 & $5.1 \%$ & $2.8 \%$ & $2.3 \%$ & $0.6 \%$ & $0.9 \%$ \\
1975 & $4.4 \%$ & $2.2 \%$ & $2.2 \%$ & $0.4 \%$ & $1.1 \%$ \\
\hline
\end{tabular}

Source:

Buliner-Thomas (1994, 271).

Table 2

Nominal Rates of Protection, Circa 1960

\begin{tabular}{lrrrrrr}
\hline \hline & $\begin{array}{r}\text { Consumer } \\
\text { Nondurables }\end{array}$ & $\begin{array}{r}\text { Consumer } \\
\text { Durables }\end{array}$ & $\begin{array}{r}\text { Semi- } \\
\text { Manufactures }\end{array}$ & $\begin{array}{r}\text { Industrial } \\
\text { Raw Materials }\end{array}$ & $\begin{array}{r}\text { Capital } \\
\text { Goods }\end{array}$ & $\begin{array}{r}\text { Overall } \\
\text { Average }\end{array}$ \\
\cline { 2 - 7 } Argentina & $176 \%$ & $266 \%$ & $95 \%$ & $55 \%$ & $98 \%$ & $131 \%$ \\
Brazil & $260 \%$ & $328 \%$ & $80 \%$ & $106 \%$ & $84 \%$ & $168 \%$ \\
Chile & $328 \%$ & $90 \%$ & $98 \%$ & $111 \%$ & $45 \%$ & $138 \%$ \\
Colombia & $247 \%$ & $108 \%$ & $28 \%$ & $57 \%$ & $18 \%$ & $112 \%$ \\
Hexico & $114 \%$ & $147 \%$ & $28 \%$ & $38 \%$ & $14 \%$ & $61 \%$ \\
Eruguay & $23 \%$ & $24 \%$ & $23 \%$ & $14 \%$ & $27 \%$ & $21 \%$ \\
EEC: & $17 \%$ & $19 \%$ & $7 \%$ & $1 \%$ & $13 \%$ & $13 \%$ \\
\hline
\end{tabular}

Source:

Bulmer-Thomas (1994. 280).

Table 3

Effective Rates of Protection, Circa 1960

\begin{tabular}{|c|c|c|c|c|}
\hline \multirow[b]{3}{*}{ Brazil $(1966)$} & \multicolumn{2}{|c|}{$\overline{\text { Consumer Durables }}$} & \multicolumn{2}{|c|}{ Manufacturing } \\
\hline & Nominal & ERP & Nominal & $\overline{\text { ERP }}$ \\
\hline & $154 \%$ & $285 \%$ & $86 \%$ & $127 \%$ \\
\hline Chile (1961) & $95 \%$ & $123 \%$ & $89 \%$ & $158 \%$ \\
\hline Mexico (1960) & $50 \%$ & $85 \%$ & $20 \%$ & $32 \%$ \\
\hline
\end{tabular}

Source:

Edwards (1993.1363).

Table 4

Distortions in Latin America, 1960-70

\begin{tabular}{|c|c|c|c|}
\hline & BMPL & LNPIPY & GXR \\
\hline All & 0.17 & $0.4 \mathrm{I}$ & 0.03 \\
\hline SW nonqualifiers & 0.23 & 0.54 & 0.03 \\
\hline SW qualifiers & 0.03 & 0.07 & 0.04 \\
\hline 1.atin Anerica & 0.12 & 0.25 & 0.07 \\
\hline Southern Cone & 0.16 & 0.39 & 0.21 \\
\hline Asia-Pacific & 0.08 & 0.21 & 0.08 \\
\hline VIC 4 & 0.10 & 0.25 & 0.04 \\
\hline
\end{tabular}

BMPL: black-market premium on the exchange rate; LNPIPY: relative price of capital goods; GXR: rate of depreciation of the curtency; SW vefers to Sachs-Warner growth criteria; see text.

Soruces:

See text and appendix 
Table 5

Distortions and Growth in Latin America, 1970-90

(a) Distortions

(b) Growth

BMPL OWTI LNPIPYGXR $\begin{gathered}\text { Latin America } \\ \text { rank (avg. of 4) }\end{gathered}$

Latin America

\begin{tabular}{|c|c|c|c|c|c|c|c|}
\hline All & 0.27 & 0.17 & 0.44 & 0.10 & & 0.014 & \\
\hline SW nonqualifiers & 0.37 & 0.21 & 0.57 & 0.14 & & 0.006 & \\
\hline SW qualifiers & 0.02 & 0.07 & 0.08 & 0.01 & & 0.032 & \\
\hline Latin America & 0.26 & 0.22 & 0.27 & 0.37 & & 0.005 & \\
\hline Southern Cone & 0.32 & 0.27 & 0.19 & 0.60 & & 0.010 & \\
\hline Asia-Pacific & 0.06 & 0.13 & 0.23 & 0.02 & & 0.034 & \\
\hline NIC4 & 0.03 & 0.06 & 0.14 & 0.00 & & 0.065 & \\
\hline Southern Cone & 0.32 & 0.27 & 0.19 & 0.60 & & 0.010 & \\
\hline Argentina & $0.33^{*}$ & $0.29^{*}$ & $0.34^{*}$ & $1.16^{*}$ & 1 & -0.009 & 4 \\
\hline Paraguay & $0.29^{*}$ & $0.46^{*}$ & $0.46^{*}$ & 0.11 & 4 & 0.021 & 15 \\
\hline Chile & $0.52^{*}$ & $0.21^{*}$ & 0.04 & $0.5 I^{*}$ & 5 & 0.009 & 12 \\
\hline Brazil & $0.29 *$ & 0.16 & 0.09 & $0.83^{*}$ & 8 & 0.025 & 18 \\
\hline Uruguay & 0.14 & $0.21^{*}$ & 0.04 & $0.4 l^{*}$ & 12 & 0.006 & 10 \\
\hline Others & 0.24 & 0.19 & 0.30 & 0.28 & & 0.003 & \\
\hline Nicaragua & $0.62 *$ & 0.15 & $0.48^{*}$ & $0.90^{*}$ & 2 & -0.030 & 1 \\
\hline Peru & 0.26 & $0.41^{*}$ & 0.25 & $0.77^{*}$ & 3 & -0.011 & 3 \\
\hline El Salvador & $0.56^{*}$ & 0.13 & $0.68^{*}$ & 0.06 & 6 & 0.000 & 6 \\
\hline Bolivia & $0.32 *$ & 0.13 & $0.26^{*}$ & $0.62 *$ & 7 & 0.000 & 5 \\
\hline Venezuela & $0.33^{*}$ & $0.18^{*}$ & 0.21 & 0.12 & 9 & -0.012 & 2 \\
\hline Costa Rica & 0.18 & 0.16 & $0.33^{*}$ & 0.13 & 10 & 0.009 & 13 \\
\hline Colombia & 0.08 & $0.3 l^{*}$ & 0.21 & 0.17 & 11 & 0.022 & 17 \\
\hline Ecuador & 0.18 & $0.28^{*}$ & -0.08 & 0.18 & 12 & 0.022 & 16 \\
\hline Guatemala & 0.14 & 0.08 & $0.5 l^{*}$ & 0.08 & 14 & 0.002 & 7 \\
\hline Mexico & 0.10 & 0.08 & 0.22 & $0.27^{*}$ & 15 & 0.019 & 14 \\
\hline Honduras & 0.14 & na & $0.36^{*}$ & 0.04 & na & 0.005 & 9 \\
\hline Panama & 0.00 & ná & 0.12 & 0.00 & na & 0.006 & 11 \\
\hline
\end{tabular}

Notes:

* denotes top 8 within Latin America in each category. GY: growth rate of per capita GDP;

LNPIPY: relative price of capital goods; BMPL: black-market premium on the exchange rate;

OWTI: own-weight tarifr incidence; GXR: rate of depreciation of the currency; see text. SW refers

to Sachs-Warner growth criteria.

Sources:

See text and appendix. 
Table 6

Growth Determinants and Unconditional Convergence

\begin{tabular}{|c|c|c|c|c|}
\hline Regiession no, & (I) & $\overline{(2)}$ & (3) & (4) \\
\hline Dependent vatiable: & Gr & GY & GY & GY \\
\hline Sample & all & SWqual & SW'nonqual & all \\
\hline$\underline{N}$ & 494 & 136 & 358 & 432 \\
\hline $\bar{R}$ squatied & .06 & .21 & .06 & .15 \\
\hline$\underline{\mathrm{SEE}}$ & 0.0364 & 0.0218 & 0.0377 & 0.0326 \\
\hline Cinstant & $-0.0083(0.66)$ & $0.1674(7.31)$ & $0.0310(1.80)$ & $0.0919(5.10)$ \\
\hline LNY0 & $0.0028(1.75)$ & $-0.0154(5.91)$ & $-0.0033(1.43)$ & $-0.0069(3.37)$ \\
\hline$O N Q$ & & & & $-0.0318(6.91)$ \\
\hline $\mathrm{PNO}$ & & & & $-0.0080(2.08)$ \\
\hline Regression no. & (5) & (6) & (7) & (8) \\
\hline Dependent variable & GYY & GY & GY & (jY \\
\hline Sample & Latin dmerica & Latin America & Asia-Pacific & Asia-Pacilic \\
\hline $\mathrm{N}$ & 68 & 60 & 60 & 48 \\
\hline$R$ squared & .04 & .10 & .00 & 19 \\
\hline SEE & 0.0317 & 0.0315 & 0.0315 & 0.0231 \\
\hline Constant & $0.1188(1.76)$ & $0.1683(2.31)$ & $0.0275(0.69)$ & $0.1959(4.80)$ \\
\hline LNYO & $-0.0143(1.69)$ & $-0.0200(2.21)$ & $0.0008(0.17)$ & $-0.0177(3.69)$ \\
\hline$O N Q$ & & & & $-0.0779(5.97)$ \\
\hline $\mathrm{PNQ}$ & & $-0.0146(1.72)$ & & $0.0290(2.04)$ \\
\hline
\end{tabular}

Notes:

GY: growth rate of per capita GDP; LNY0: natural log of initial GDP per capita; PNQ: political non-qualifier country in the Sachs-Warner classification; ONQ: openness non-qualifier country in the Sachs-Warner classification; SW qual denotes qualifiers in the Sachs-Warner growth criteria; SWnonqual denotes nonqualifiers; see text.

Sources:

See text and appendix.

Table 7

Growth Determinants and Conditional Convergence: Reduced Form Estimation

\begin{tabular}{|c|c|c|}
\hline Regression no. & (9) & \\
\hline Dependent variable & $\underline{G Y}$ & \\
\hline Sample & all & \\
\hline$\underline{N}$ & 250 & ANOVA \\
\hline $\bar{R}$ squated & .31 & Sums of \\
\hline$\underline{\mathrm{SEE}}$ & 0.0279 & Squares \\
\hline Constant & $0.2147(4.56)$ & 0.0598 \\
\hline L.NYO & $-0.0156(3.69)$ & 0.0106 \\
\hline$\underline{P Y R}+S Y R+0$ & $0.0001(0.11)$ & 0.0000 \\
\hline $\operatorname{POP} 15+1)$ & $-0.0906(1.55)$ & 0.0019 \\
\hline PoP $65+0$ & $-0.1 .455(1.20)$ & 0.0011 \\
\hline PYQ & $-0.0033(0.66)$ & 0.0003 \\
\hline BMPL & $-0.0213(4.22)$ & 0.0139 \\
\hline OWTI & $-0.0063(0.57)$ & 0.0003 \\
\hline$\underline{G}$ & $-0.0009(3.01)$ & 0.0070 \\
\hline LNPIPY & $-0.0214(3.56)$ & 0.0099 \\
\hline GXR & $-0.0332(3.89)$ & 0.0118 \\
\hline LLY & $0.0035(0.40)$ & 0.0001 \\
\hline PNXI & $-0.0129(0.78)$ & 0.0005 \\
\hline Residuat & & 0.1847 \\
\hline Total & & 0.2686 \\
\hline
\end{tabular}

Notes:

GY' growth rate of per capita GDP; LNY0: natural log of initial GDP per capita; PYR +SYR +0; initial years of primary and secondiury schooling per person; $\mathrm{P}+\mathrm{S}$; average enrollment rate in primary and secondary schools ; $\mathrm{CI}$ : ratio of real gross investment to real GDP; GPOP: growth rate of population; FDIXY: ratio of inbound foreign direct investment to (il)P: PNXI: netasure of primary product net export intensity; POP15+0, POP65+0: initial share of population aged under 15, wer 65; Gr: shate of government spending in GDP; PNQ: political non-qualifier country in the Saclis-Warner c lassification; LNPIPY: relative price of capital goods ; BMPL: black-market prenium on the exchange rate; OWT1: own-weight tariff incidence; ONQ: openness non-qualifier country in the Sachs-Warner Classilication: (XXR: rate of depreciation of the currency: LLY: ratio of liquid liabilities in the financial system to GDP.

Sonmes:

See text and appendix 
Table 8

Growth Determinants and Conditional Convergence: Structural Equation Estimation

\begin{tabular}{|c|c|c|c|c|}
\hline Regression no. & $(10)$ & (11) & $(\overline{12)}$ & $(13)$ \\
\hline Dependent variable & GY & $\underline{G Y}$ & $\underline{G}$ & $G Y$ \\
\hline Sample & $\overline{\text { all }}$ & Lacin America & Asia-Pacific & $\overline{\text { all }}$ \\
\hline II & 461 & 68 & 56 & 312 \\
\hline$\overline{\mathrm{R}}$ squared & .19 & .28 & .21 & .16 \\
\hline$\underline{\mathrm{SEE}}$ & 0.0329 & 0.0281 & 0.0283 & 0.0313 \\
\hline$\overline{C o n s t a n t}$ & $0.0961(5.85)$ & $0.2406(3.19)$ & $0.1151(2.34)$ & $0.0508(2.34)$ \\
\hline LNYO & $-0.0117(4.45)$ & $-0.0253(2.62)$ & $-0.0178(2.69)$ & $-0.0054(1.59)$ \\
\hline$P+S$ & $-0.0020(0.34)$ & $-0.0443(2.31)$ & $0.0236(1.45)$ & $-0.0081(1.14)$ \\
\hline CI & $0.0017(7.51)$ & $0.0036(4.48)$ & $0.0017(2.37)$ & $0.0015(5.24)$ \\
\hline FDLXY & & & & $0.2046(1.84)$ \\
\hline GPOP & $-0.8716(5.94)$ & $-1.4279(2.39)$ & $-0.6071(0.89)$ & $-0.6708(3.65)$ \\
\hline Regression no. & $(14)$ & $(15)$ & $(16)$ & $(17)$ \\
\hline Dependent variable & $\underline{\mathrm{CY}}$ & $\mathrm{GY}$ & GY & $\underline{G Y}$ \\
\hline Sample & ex. Singapore/Botswana & all & SWqual & SWnonqual \\
\hline$\underline{1}$ & 306 & 413 & 133 & $328^{\circ}$ \\
\hline $\mathbf{R}$ squated & .13 & .26 & .32 & .15 \\
\hline SEE & 0.0313 & 0.0305 & 0.0199 & 0.035 \\
\hline Constant & $0.0472(2.15)$ & $0.1579(7.63)$ & $0.2177(8.15)$ & $0.0975(4.95)$ \\
\hline LNYO & $-0.0049(1.43)$ & $-0.0188(6.14)$ & $-0.0272(6.82)$ & $-0.0114(3.49)$ \\
\hline$\underline{\mathrm{P}+\mathrm{S}}$ & $-0.0069(0.97)$ & $0.0034(0.56)$ & $0.0221(2.52)$ & $-0.0083(1.23)$ \\
\hline CI & $0.0014(4.72)$ & $0.0015(6.41)$ & $0.0007(2.36)$ & $0.0017(5.97)$ \\
\hline FDIXY & $0.0967(0.73)$ & & & \\
\hline C.POP & $-0.6458(3.47)$ & $-0.4475(2.71)$ & $-0.1159(0.64)$ & $-0.8734(-1.19)$ \\
\hline ONQ & & $-0.0224(4.73)$ & & \\
\hline PNO & & $-0.0102(2.74)$ & & \\
\hline
\end{tabular}

Soles and Sources:

See Table 7 , text and appendix.

Table 9

Growth Determinants and Conditional Convergence: Augmented Structural Equation Estimation

\begin{tabular}{|c|c|c|c|}
\hline Regression no. & $(18)$ & $(19)$ & $(18\} \times 119)$ \\
\hline Dependent variable & $\underline{\mathrm{GY}}$ & $\underline{\mathrm{GY}}$ & \\
\hline Sample & all & $\overline{\text { all }}$ & \\
\hline$\underline{I}$ & 244 & 236 & Hatusman \\
\hline $\mathrm{R}$ squared & .37 & .31 & Endogeneily \\
\hline$\underline{\mathrm{SEE}}$ & 0.0269 & 0.0285 & Test \\
\hline Method & OLS & 2SLS & ( $\mathrm{P}$ value) \\
\hline Constant & $0.1807(3.76)$ & $-0.3847(0.69)$ & \\
\hline LNYQ & $-0.0182(4.06)$ & $0.1107(1.03)$ & \\
\hline$\underline{\mathrm{PYR}+\mathrm{SYR}+0}$ & $0.0003(0.24)$ & $0.0060(0.74)$ & \\
\hline $\mathrm{POP} 15+0$ & $0.0003(0.01)$ & $0.8614(1.12)$ & \\
\hline$\underline{\mathrm{POP} 65+0}$ & $-0.0859(0.71)$ & $-1.9065(1.67)$ & \\
\hline$\overline{P N Q}$ & $-0.0027(0.56)$ & $-0.0585(1.32)$ & \\
\hline B.MPL & $-0.0190(3.76)$ & $0.2075(1.16) \dagger$ & 0.46 \\
\hline OWTI & $-0.0005(0.05)$ & $0.0950(1.00)$ & \\
\hline (i) & $-0.0010(3.35)$ & $0.0001(0.11)$ & \\
\hline L.YPIPY & $-0.0096(1.28)$ & $0.0715(0.59) \dagger$ & 0.83 \\
\hline GXR & $-0.0272(3.14)$ & $-0.1336(1.73)$ & \\
\hline$\underline{\text { I.L.Y' }}$ & $0.0021(0.21)$ & $-0.1418(1.01)^{\dagger}$ & 0.62 \\
\hline$P \times 1$ & $-0.0184(1.13)$ & $0.1699(1.23)$ & \\
\hline$\underline{P+S}$ & $0.002 .4(0.25)$ & $-(0.3172(1.06) \dagger$ & 0.97 \\
\hline$\underline{C I}$ & $(0.0011(2.76)$ & $0.0062(0.83) \dagger$ & 0.46 \\
\hline GPOP & $-0.5539(2.15)$ & $-20.6041(1.31) \dagger$ & 0.62 \\
\hline
\end{tabular}

Votes and Sunnes

See lable 7, text and appendix. 
Table 10

Growth Determinants: Behavioral Equation Estimation

\begin{tabular}{|c|c|c|c|}
\hline & & & \\
\hline Regression no. & $(20)$ & $(21)$ & $(22)$ \\
\hline Dependent valtable & (1) & GPOP & $\underline{\mathrm{P}+\mathrm{S}}$ \\
\hline Sample & all & all & all \\
\hline$\underline{N}$ & 236 & 225 & 230 \\
\hline$\overline{\mathrm{R}}$ squared & .74 & .54 & .85 \\
\hline$\underline{\mathrm{SEE}}$ & 4.562 & 0.0083 & 0.1657 \\
\hline Constant & $73.7032(4.84)$ & $0.0334(3.44)$ & $-1.2867(4.44)$ \\
\hline LNYO & $-14.0049(3.69)$ & $0.0012(0.77)$ & $0.3001(9.63)$ \\
\hline PY'R+SYR+0 & $-1.0449(3.26)$ & $-0.0008(1.65)$ & $0.0402(4.69)$ \\
\hline POP $15+0$ & $-100.9020(4.01)$ & & $2.2437(4.48)$ \\
\hline POP65+0 & $143.7300(2.35)$ & & $-3.6764(4.26)$ \\
\hline PNQ & $5.7502(3.20)$ & $0.0011(0.74)$ & $0.0039(0.13)$ \\
\hline $\mathrm{BMPL}$ & $-23.2958(3.85)$ & & \\
\hline OWTI & $-12.4540(3.85)$ & & \\
\hline$\underline{G}$ & $-0.0407(0.56)$ & $0.0001(0.74)$ & $0.0070(3.74)$ \\
\hline LNPIPY & $-16.1287(7.07) \dagger$ & & \\
\hline GXR & $9.8495(2.64)$ & & \\
\hline$\underline{L L Y}$ & $18.5170(5.38)$ & $-0.0029(1.09)$ & $-0.2283(3.12)^{\dagger}$ \\
\hline PNXI & $-17.8299(3.06)$ & $0.0234(4.84)$ & $0.2272(2.08)$ \\
\hline$\underline{P+S}$ & $39.2374(4.22) \dagger$ & $-0.0186(3.96) \dagger$ & \\
\hline CI & & $0.0002(1.45)$ & $0.0090(4.38)$ \\
\hline GPOP & $2059.0300(3.81)^{\dagger}$ & & $-38.3005(7.72) \dagger$ \\
\hline Regression no. & $(\overline{23})$ & (24) & $(25)$ \\
\hline Dependent variable & $\underline{B M P L}$ & $\underline{\text { LISY }}$ & LNPIPY \\
\hline Simple & ill & $\overline{\text { all }}$ & all \\
\hline$\underline{\perp}$ & 143 & 223 & 236 \\
\hline$\vec{R}$ squared & .52 & .51 & .29 \\
\hline$\underline{\mathrm{SEE}}$ & 0.1891 & 0.2029 & 0.3414 \\
\hline Constant & $0.4788(1.31)$ & $-0.3757(1.56)$ & $-0.1911(3.23)$ \\
\hline$\underline{\mathrm{LVYO}}$ & $-0.0648 \cdot(1.44)$ & $0.0701(2.00)$ & \\
\hline PYR +SYR+0 & $-0.0032(0.23)$ & $-0.0173(1.97)$ & \\
\hline \multicolumn{4}{|l|}{$\overline{P O P} 15+0$} \\
\hline \multicolumn{4}{|l|}{$\mathrm{POP} 65+0$} \\
\hline PNO & $0.1816(3.19)$ & $-0.0124(0.30)$ & \\
\hline BMPL & & $0.0788(2.06)$ & $0.1654(2.16) t$ \\
\hline OWTI & $-0.0449(0.33)$ & $-0.2262(2.80)$ & $0.2772(2.26)$ \\
\hline $\begin{array}{l}\text { Ci } \\
\text { LNPIPY }\end{array}$ & $0.0106(3.17)$ & $0.0022(0.94)$ & $0.0219(6.6 \cdot 1)$ \\
\hline GXR & $0.4751(5.99)$ & $-0.2110(2.97)$ & \\
\hline$\underline{1.1 . Y}$ & & & \\
\hline$\overline{\mathrm{PNXI}}$ & $-0.0124(0.07)$ & $-0.3661(3.14)$ & $0.2390(1.34)$ \\
\hline$\overline{P+S}$ & & & \\
\hline$\frac{C I}{G P O P}$ & & $0.0189(4.39) \dagger$ & \\
\hline
\end{tabular}

Yotes and Sources:

See Table 7. text and appendix. 
Table 11

Sample Statistics and Growth-Rate Differences in Latin America (a) Sample Means of Variables

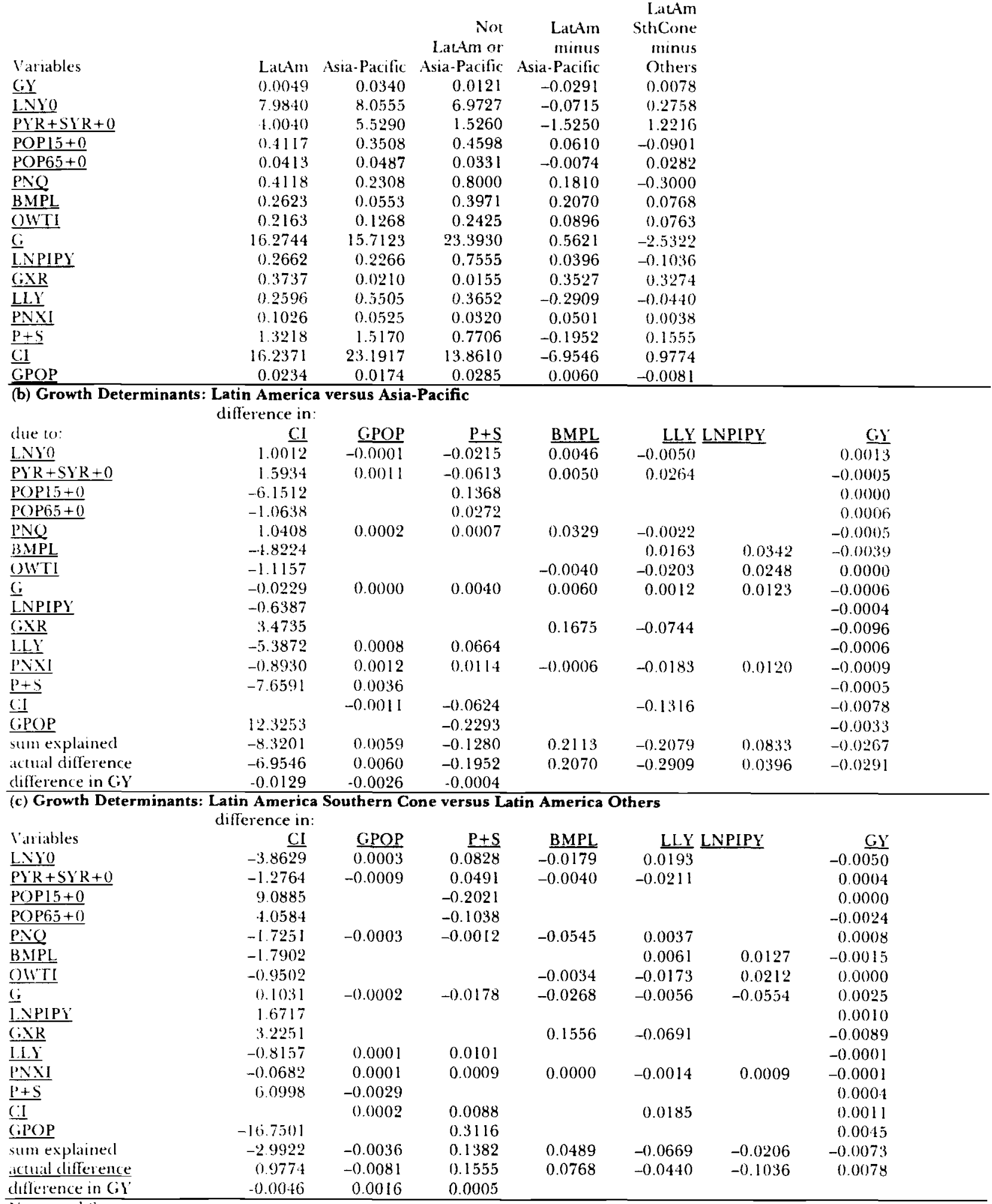

Votes and Sources:

See $[$ able $7,8,9,10$. text and appendix. In (b) and (c): columns from Regressions (20)-(25) and (18); last row from Regression (15). 